\title{
INTRA-SESSION AND INTER-SESSION RELIABILITY OF ELECTROMYOGRAPHY IN LEG EXTENSION DURING MAXIMUM VOLUNTARY ISOMETRIC CONTRACTIONS OF QUADRICEPS: THE EFFECT OF KNEE ANGLE
}

\author{
Filip Kukić ${ }^{1}$, Aleksandar Stanković ${ }^{3}$, Vladimir Mrdaković², Dusko Ilić ${ }^{2}$ Miloš Ubovićn \\ ${ }^{1}$ Strategic management and performance improvement Department, Abu Dhabi Police, United Arab Emirates \\ ${ }^{2}$ University of Belgrade, Faculty of Sport and Physical Education, Serbia \\ ${ }^{3}$ Profex, Academy of Healthy Living, Belgrade, Serbia
}

\begin{abstract}
Numerous factors can influence the reliability of the signal obtained by electromyography EMG among which the type of contraction is practically fundamental. This study aimed to investigate intra- and inter-session reliability of EMG for maximal voluntary isometric contraction (MVIC) of the knee extensors at different joint angles. Nine healthy male students from the Faculty of Sport and Physical Education voluntarily joined the experiment. Main characteristics of the subjects were: age $23 \pm 1$ years, body weight $80.8 \pm 7.8 \mathrm{~kg}$ and body height $182 \pm 7 \mathrm{~cm}$. EMG signal from three surface heads of quadriceps femoris was recorded - vastus lateralis (VL), vastus medialis (VM), and rectus femoris (RF). Subjects had to perform 3 MVIC as fast as possible, as strong as possible at 6 different knee joint angles on 2 occasions separated by 7-8 days. The intra-class coefficient of correlation (ICC) was used to identify relative intra- and inter-session reliability, while standard error of measurement (SEM) was used to calculate the absolute reliability of each tested muscle. All muscles showed high intra-session reliability ( $\mathrm{ICC}=0.488-0.988$ and $\mathrm{SEM}=1.38-11.35)$. VL showed good inter-session reliability for most of the conditions (ICC $=0.603-0.948$ ), $\mathrm{VM}$ for two knee angles $\left(\mathrm{ICC} 120^{\circ}=0.764\right.$ and $\mathrm{ICC} 130^{\circ}=0.788$ ), $\mathrm{RF}$ was not reliable for any knee angle. This study indicates that RF does not need to be used in EMG testing in leg extension MVIC due to lack of reliability between two sessions, and If EMG RMS from VL and VM will be tested, knee angle of $120^{\circ}$ should be used for the testing.
\end{abstract}

Keywords: TESTING / BETWEEN-DAY / WITHIN-DAY / REPEATBILITY

\section{INTRODUCTION}

The surface electromyography (EMG) signal represents motor unit's neural activity recorded on the muscle's surface. Activation of the motor unit leads to contraction of every muscle fibre innervated by that motor unit which brings the production of the muscle force. Furthermore, the force produced by muscle partially is a result of the amount and timing of the motor unit activity (Wang and Butchman, 2002; Farina et al., 2014; Enoka and Duchateau, 2015). Numerous extrinsic and intrinsic factors can influence the quality of the signal obtained by the EMG: technical error, equipment error, learning effects, biological variance (Ball and Scurr, 2010; Burden, 2010; De
Luca, 1997; Larsson, 2003). To overcome some of the factors and to make EMG signal comparable between the muscles and between tests, the signal should be normalized (Mirka, 1991; Burnett et al., 2007; Dankaerts et al., 2005). Because muscle activation varies with a change in joint angle, comparison of the EMG signal in different muscle lengths should be done with a normalized signal as a relativized level of muscle activity (Mirka, 1991; Merletti et al., 1999). Regarding practical applicability, the use of normalisation method is needed for the reliability evaluation of the EMG signal.

In recent history, different approaches to reliability were reported. Mostly, reliability was investigated for different intensities (Campy et al., 2009; Larsson 
et al., 2003; Mathur et al., 2005; Rainoldi et al., 2001; Smith et al., 2012). Campy et al (2009) examined the hamstring muscles at different contraction intensities and found high test-retest reliability coefficients (ICC=0.70-0.92 and SEM=9.72-24.94\%) only for the medial hamstring across low to moderately high isometric contraction intensities, $10-60 \%$ of maximal voluntary contraction (MVC). In the same study, lateral hamstring muscle showed moderate reliability coefficient (ICC $=0.57-0.68$ and SEM $=13.12-21.35 \%$ ) only at low contraction intensities, $10-30 \%$ of MVC (Campy et al., 2009).Another study demonstrated high reliability (ICC $=0.80-0.95$ and SEM=9-69) for knee extensor muscles for two sets of 100 dynamic maximum concentric right knee extensions separated by 7-8 days (Larsson et al., 2003). Mathur et al (2005) investigated the reliability of median frequency and amplitude of EMG at $80 \%$ and $20 \%$ of maximal voluntary contraction held to exhaustion. For both, median frequency and amplitude, the initial, final and normalized EMG showed moderate to high reliability for vastus lateralis (VL), vastus medialis (VM) and rectus femoris (RF) at both contraction levels: ICC = 0.59-0.88 for MDF; ICC $=0.58-0.99$ for amplitude (Mathur et al., 2005). Similarly, Rainoldi et al (2001) showed a high level of reliability (ICC $>70 \%$ ) for 50 seconds sustained contraction at 50\% MVC. In the weight-bearing control study, Smith et al (2012) reported high inter-session reliability of the quadriceps muscles in most of the tested conditions, ICC $=0.60$ 0.94 . In the same study authors found similar results for the intra-session reliability because ICC was from 0.63-0.95.

When it comes to intra-session reliability, many studies showed moderate to high level of reliability, depending on the task used (Larsson et al., 1999; Fauth et al., 2010, Smoliga et al., 2010; Smith; 2012; Worrel et al., 1998). Larsson et al (1999) aimed to investigate the during-the-day reproducibility by using the protocol that involves 10 maximal dynamic extensions with a one-hour rest. They followed the EMG signal of VL, RF and VM and the results showed a high level of reliability for all muscles, ICC $=0.83-0.98$ but VL was the most reliable (Larsson et al., 1999). Another study of reliability included 3 different tasks maximal voluntary isometric contraction (MVIC), jump from the height and cutting and the reliability of EMG was very high with all ICC values greater than 0.80 (Fauth et al., 2005). Smoliga et al (2010) investigated the reliability of the EMG in competitive runners. They calculated ICC for 25 consecutive strides and found ICC $>0.80$ for 7 out of 13 tested muscles where VL and RF had ICC $<0.80$ with RF more reliable than VL, ICC for $\mathrm{RF}=0.794$ and ICC for $\mathrm{VL}=0.394$ (Smoliga et al., 2010). In the study with lateral step-up conditions, Worrel et al (1998) found high intra-session reliability with ICC ranging from $0.89-0.98$ for VM and VL and 0.67-0.99 for hamstring and gluteus maximus. On the other side in the same study was reported that inter-session reliability ranged from poor to moderate with ICC ranging from $0.06-0.67$ and $0.34-83$ for the same muscle groups (Worrel et al., 1998).

Only 2 out of 9 above mentioned studies dealt with both, the inter- and intra-session reliability (Worrel et al., 1998; Smith et al., 2012) and they had different results. Both studies reported good EMG reliability for the intra-session repetitions, but one study reported poor to moderate reliability EMG for inter-session (Worrel et al., 1998) while another study reported moderate to high reliability of the EMG for inter-session design (Smith et al., 2012). It seems that there is a certain amount of the studies that explained reliability of the EMG in various study designs with different tasks. However, to our knowledge, there is a lack of the evidence exist regarding the reliability for the basic relationship muscle activity - muscle length (EMG - L), during MVIC. Also, not many studies dealt with both intra- and inter-session reliability, and there is an existing inconsistency with the results. Thus, more data regarding that matter is needed. Therefore, the purpose of this study was to investigate the effect of knee angle on intra-session and inter-session reliability of the EMG for MVIC. Four hypotheses will be tested: 1) intra-session will show high reliability across all knee angles and muscles; 2 ) inter-session reliability will have moderate to high level of reliability depending on the knee joint angle, and the muscle followed among which VL will be the most reliable.

\section{METHODS}

Since this study included 9 participants and two testing session, this study could be classified as a pilot study conducted by the laboratory principles using cluster sample (Hopkins, 2000).

\section{Participants}

Nine healthy male students from the Faculty of 
Sport and Physical Education voluntarily joined the experiment. Main characteristics of the subjects were: age $23 \pm 1$ years, body weight $80.8 \pm 7.8 \mathrm{~kg}$ and body height $182 \pm 7 \mathrm{~cm}$. All subjects were involved in physical activity minimum 3 times a week for last 3 years. There was no evidence of any knee injury or neurological disorders in their medical history. All participants were informed about the purpose of the study, and they could leave the study at any moment. The study was approved by the ethical committee of the Faculty of Sport and Physical Education following the Declaration of Helsinki regarding human experimentation.

\section{Equipment}

\section{Electrode placement}

EMG signal from three surface heads of the quadriceps femoris were recorded: VL, VM, and RF using surface Delsys Single differential Surface EMG sensors (Delsys Ink., Boston, MA). Electrodes were placed by Delsys manual guide (Delsys technical note 101: EMG sensor placement). A ground electrode was placed on the hip joint of the opposite leg. The skin was shaved at the location of the electrode placement, cleaned with alcohol, and lubricated with ultrasound gel for better electrical conductivity. The electrodes were placed on the most prominent point of the muscle belly following Delsys manual guide (De Luca, 2002). Electrode positions were marked on the skin by the waterproof marker so the day to day position can be controlled. To avoid cross-talk, electrodes were placed at the minimum of $3 \mathrm{~cm}$ from each other and tightly fixed with medical tape around the leg and over the electrodes, so there is no movement of the electrodes. Additional tapes were used to fix the cables.

\section{EMG signal acquisition and processing}

Single differential multichannel EMG amplifier of $1000 \mathrm{~Hz}$ was used to register EMG signal. Sampling frequency was $2000 \mathrm{~Hz}$, and A/D converter with 12bit precision in the voltage range of $\pm 0.002 \mathrm{~V}$.

Original Delsys software (Delsys EMG works 4.1) was used for signal processing. To estimate muscle activity level, root mean square (RMS) calculation was used. According to the De Luca (1997), RMS is a measure of the power of the EMG signal. Window length was $100 \mathrm{~ms}$ with $80 \mathrm{~ms}$ of overlapping. For further statistical analysis, first 2 seconds of each contraction were normalized relative to highest maximal voluntary contraction (MVC). The beginning of the contraction was followed by the fourth channel where foot switcher was connected. Foot switcher was positioned on the front edge of the tibia where the lower leg was in contact with the lever arm. The change in voltage caused by the pressure of the tibia on the lever arm was recorded, and it presented the beginning of the contraction.

\section{Familiarization and settings}

Subjects came to the laboratory on 2 occasions: one week before the first testing day and then 3 days before the first testing day to get familiar with the testing procedures. First familiarization session was used for the setting of the isokinetic chair (Kin-Com, Chattanooga Group, Inc. Chattanooga TN) according to subject's anthropometry and to get familiar with the contraction mode. The horizontal position of the of the thigh was fixed for all participants, while the back support and whole chair were adjusted to fix the hip joint position in $90^{\circ}$. The axis of rotation of the dynamometer and the axis of the rotation of the knee joint were aligned by moving the head of the dynamometer. The same principle was used to parallelly align dynamometer lever arm and tibia. Two separate crossbelts were used to fix upper body to the armchair, one belt fixed hips to the chair, and one belt was used to fix the thigh to the chair. Force detection system was positioned $1 \mathrm{~cm}$ above the lateral malleolus. The chair positions for every knee joint angle were marked and written down. Keeping the same position of the chair for both testing days kept technical error of the measurement at the minimum. Second familiarization session was used for getting more familiar with the contraction mode and for marking the places for electrodes placement.

\section{Testing procedure}

Before the testing, all participants did warm up protocol of 10 minutes cycling on the bicycle ergometer, followed by 3-5 minutes dynamic stretching. After stretching, electrodes were positioned and with fixed electrodes participants were positioned in already individually prepared Kin-Com dynamometer chair. Subjects had to perform 3 maximal voluntary isometric contractions (MVIC) as fast as possible, as strong as possible in 6 different, randomly selected, knee joint angles. Tested angles were $80^{\circ}, 90^{\circ}, 100^{\circ}$, $110^{\circ}, 120^{\circ}$, and $130^{\circ}$ of knee extension (angle between femur and tibia). Duration of each contraction was 
3 seconds. Rest period between contractions was 4560s. After the testing in one joint angle was finished, participants had 3-5 minutes of rest, and during that time, the next joint angle was set. Contraction correctness was controlled by the force output. Every contraction that contained stretch-shortening cycle or lasted less than $3 \mathrm{~s}$ was repeated until 3 successful contractions were recorded. Subjects could see the force output so they can give their best in every contraction. Also, for better motivation, they were highly supported by the testing team. The identical protocol with the same order of knee angles has been conducted in both testing sessions.

\section{Statistical analysis}

All RMS values were written in Microsoft Excel for further analysis. The descriptive statistics for mean and standard deviation was conducted in Microsoft Excel. For reliability analysis software SPSS Statistics 17 was used. Intraclass Coefficient of Correlation with 95\% confidence interval ( ICC $_{2,1}$ two-way random effect) was used to identify within and between-day reliability (Larsson et al., 2003), using $\mathrm{p}<0.05$ level of significance. ICC has been chosen as a measure of relative reliability because it considers between and within-subject variance (Larsson et al., 2003; Mathur et al., 2005; Wier, 2005). ICC values of more than 0.75 represent high reliability, values of 0.60-0.74 represents medium reliability, and low or lack of the reliability would be for all values below 0.60 (Smith et al., 2012). For acceptable reliability level, the value of 0.75 was taken as per previous study (Dankaerts et al., 2004). Sometimes a negative ICC can occur which means that the within-subject variance exceeds the between-subject variance (Larsson et al., 2003; Rain- oldi et al., 2001). Variability among subjects must be significant. If that is not the case, limits of the ICC do not match the theoretical limits of $0.0-1.0$, and it cannot be considered valid. Practically, it is possible for ratios to range from negative to positive infinity. In that case, the alternative measure of reliability - standard error of measurement (SEM) was used to express the absolute reliability of the measure (Smith et al., 2012). Since there were two testing sessions and three trails for each knee angle, additionally paired-sample T-test was used to determine if differences in normalized EMG magnitudes occurred between testing sessions (Smith et al., 2012). One-way ANOVA was used to test if differences existed between three trails (Larsson et al., 1999). In both statistical analyses, the level of significance was set at $a<0.05$. The standard error of measurement (SEM) was used to calculate the absolute reliability between two testing sessions and is determined from the standard deviation of the scores. The smaller the SEM, the better result is (Wier, 2005; Mathur et al., 2005).

\section{RESULTS}

Simple descriptive statistics shows the differences between test-retest means and standard deviations of normalized EMG signal for each tested muscle. Figures 1-3 show that VL has the smallest differences between two testing sessions comparing to other two tested muscles. The smallest differences in VM occurred at the knee angle of $120^{\circ}$ and $130^{\circ}$ (Figure 2). In RF only knee angle of $110^{\circ}$ seem to have a small difference between means (Figure 3 ). 


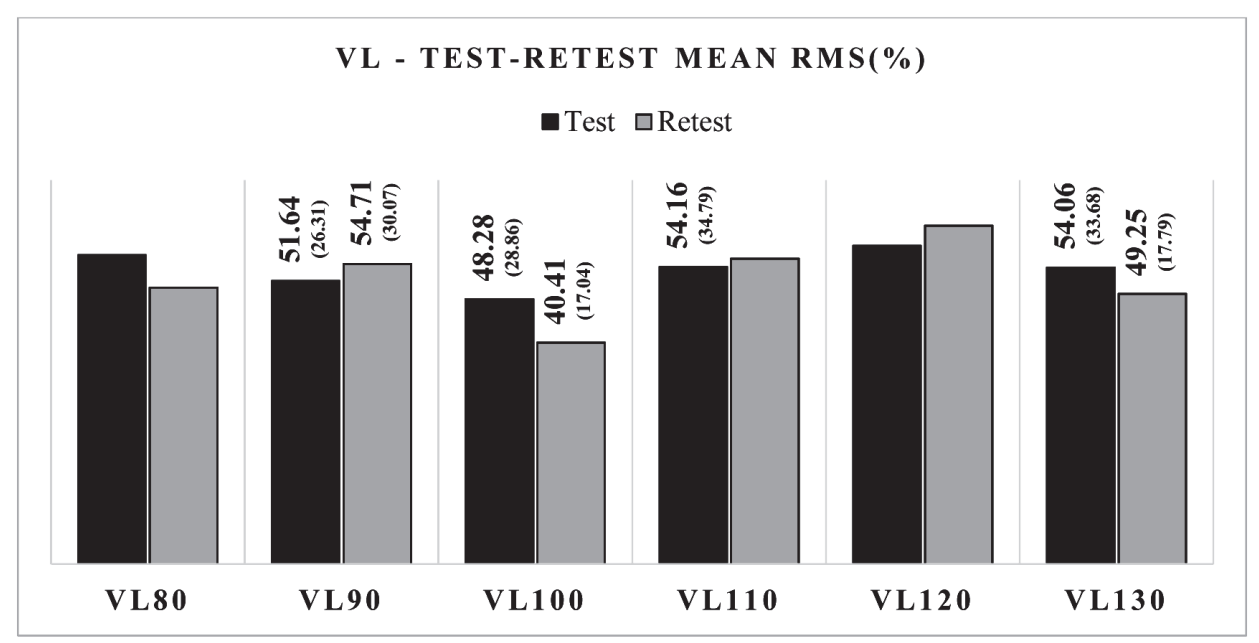

Figure 1. Descriptive statistics for mean and standard deviation for both testing days in VL.

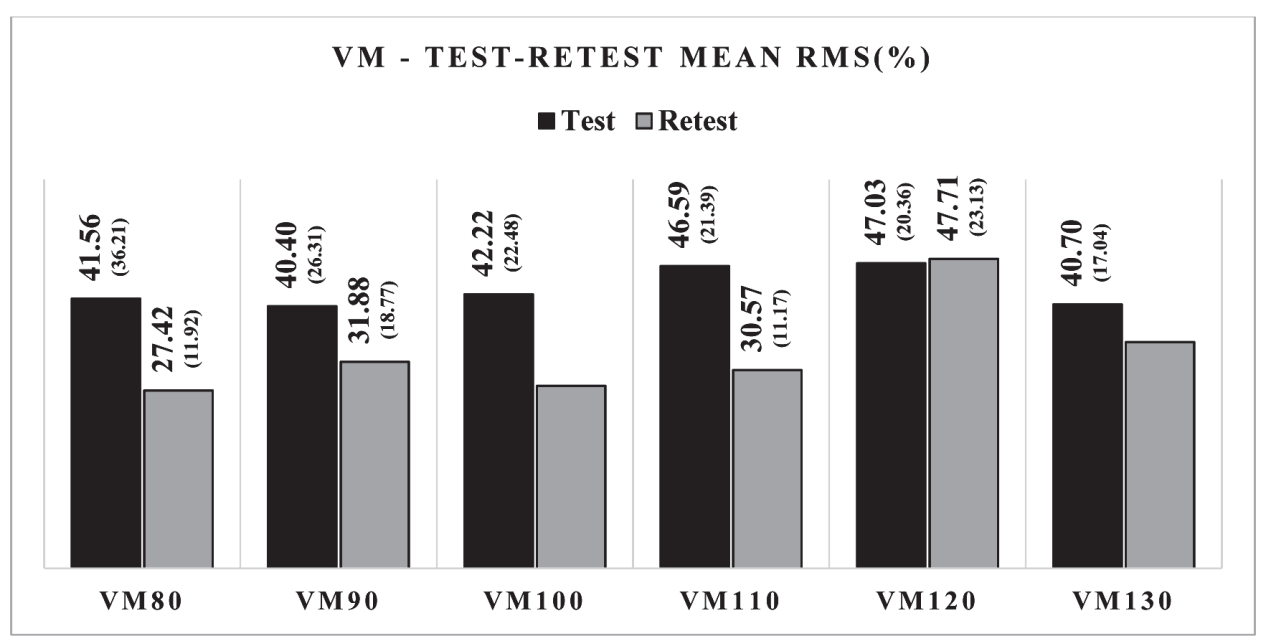

Figure 2. Descriptive statistics for mean and standard deviation for both testing days in VM

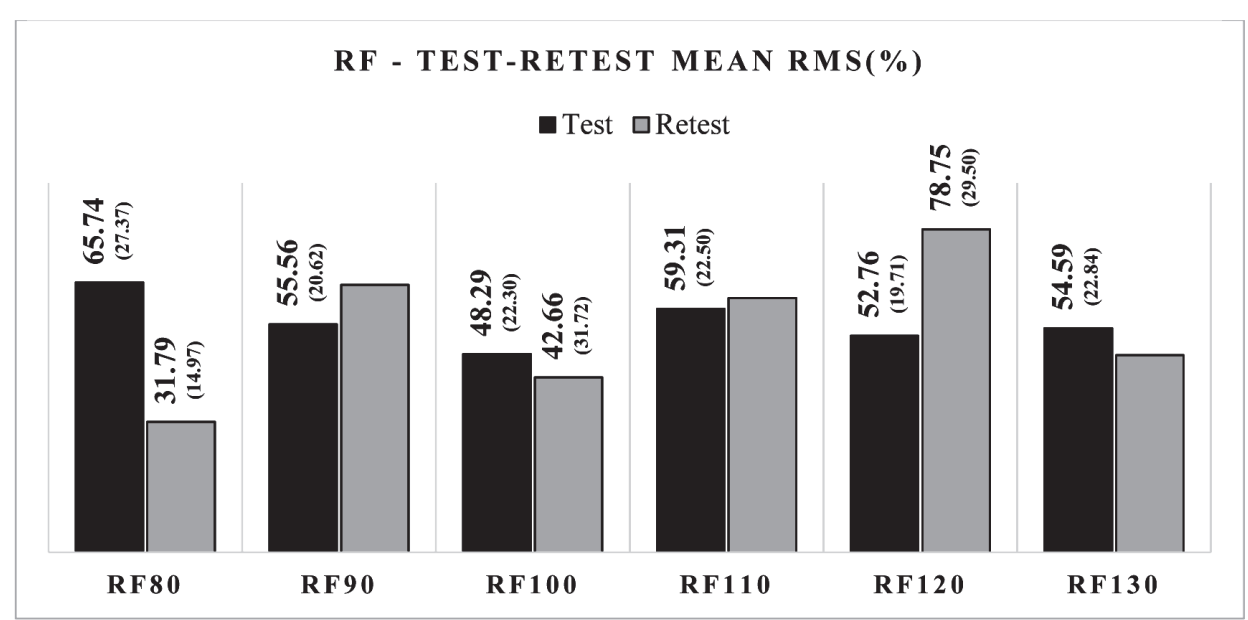

Figure 3. Descriptive statistics for mean and standard deviation for both testing days in RF. 


\section{Intra-session reliability}

Table 1 shows the results of absolute and relative intra-session reliability among 3 consecutive trials. ANOVA detected significant differences between means only in VL and VM at the knee angle of $110^{\circ}$ (Sig $=0.021$ for VL and 0.011 for VM). Results for all other tested angles for each muscle did not show any significant difference in trail-trail means.

Table 1. Intra-session reliability statistics for all knee angles and muscles.

\begin{tabular}{lllll}
\hline Muscle & $\begin{array}{l}\text { Knee } \\
\text { angle }\end{array}$ & $\begin{array}{l}\text { ANO- } \\
\text { VA }\end{array}$ & ICC & SEM \\
& & Sig & & \\
\hline VL & \multirow{2}{*}{0.546} & 0.975 & 5.32 \\
VM & 0.898 & 0.976 & 1.85 \\
RF & & 0.253 & 0.956 & 5.26 \\
\hline VL & & 0.684 & 0.979 & 6.64 \\
VM & 90 & 0.546 & 0.970 & 2.20 \\
RF & & 0.793 & 0.962 & 2.99 \\
\hline VL & & 0.348 & 0.956 & 3.63 \\
VM & 100 & 0.590 & 0.966 & 1.80 \\
RF & & 0.079 & 0.944 & 4.36 \\
\hline VL & & 0.021 & 0.988 & 3.60 \\
VM & 110 & 0.011 & 0.985 & 1.38 \\
RF & & 0.602 & 0.795 & 2.95 \\
\hline VL & & 0.600 & 0.982 & 6.11 \\
VM & 120 & 0.250 & 0.922 & 7.15 \\
RF & & 0.343 & 0.448 & 7.28 \\
\hline VL & & 0.382 & 0.846 & 11.73 \\
VM & 130 & 0.940 & 0.955 & 3.61 \\
RF & & 0.315 & 0.939 & 4.90 \\
\hline
\end{tabular}

ICC results from table 1 indicate moderate to high reliability for all muscles across all joint except RF at $120^{\circ}$ which is the only non-reliable trail-trail result in this study. ANOVA results for VL and VM from the angle of $110^{\circ}$ are shown to be highly reliable according to ICC results (0.988 and 0.985 VL for VM). Furthermore, SEM values for these two muscles are smallest at the same angle (3.60 and 1.38, respectively). All SEM values were relatively low which makes that absolute intra-session reliability relatively high (Table 1). Almost all SEM results were in range of 1.38-7.28, except VL at $130^{\circ}$ which was slightly higher (11.73). In other words, 95\% confidence interval in which the true results of 3 consecutive trails are likely to fall is relatively narrow, which could also be an indicator of the good validity of EMG. Practically, when it comes to trail-trail analysis, use of EMG is a very precise method.

\section{Inter-session reliability}

Table 2 shows the results of absolute and relative inter-session reliability. According to T-test statistical analysis, VL mean values from 2 testing sessions are not significantly different for all tested knee joint angles with the highest $p$-value at $110^{\circ}(p=0.853)$ and smallest at $100^{\circ}(p=0.163)$. VM and RF also did not show a significant difference between means from two testing session except RF at the angle of $80^{\circ}$ $(p=0.006)$. The smallest difference for $\mathrm{VM}$ was found at the knee angle of $120^{\circ}$, and for RF at $110^{\circ}(p=0.869)$. In terms of consistency, VL showed the most consistent reliability relative to knee joint angles, while in terms of the best reliability with the smallest difference between means VM showed the highest $p$-value at $120^{\circ}$ of knee angle. Overall, T-test showed that VM had the lowest $p$ values among 3 followed muscles except at the $120^{\circ}$ of knee angle where VM was the most reliable muscle. 
Table 2. Inter-session reliability statistics for all knee angles and muscles.

\begin{tabular}{|c|c|c|c|c|}
\hline Muscle & Knee angle & $\begin{array}{l}\text { T-test } \\
p \text { value }\end{array}$ & $\mathrm{ICC}$ & SEM \\
\hline VL & & 0.696 & 0.603 & 25.09 \\
\hline $\mathrm{VM}$ & 80 & 0.162 & 0.507 & 15.63 \\
\hline $\mathrm{RF}$ & & 0.006 & 0.197 & 18.97 \\
\hline VL & & 0.547 & 0.933 & 7.30 \\
\hline VM & 90 & 0.334 & 0.578 & 14.64 \\
\hline $\mathrm{RF}$ & & 0.401 & 0.341 & 20.47 \\
\hline VL & & 0.163 & 0.867 & 8.37 \\
\hline $\mathrm{VM}$ & 100 & 0.053 & 0.501 & 11.35 \\
\hline $\mathrm{RF}$ & & 0.667 & 0.104 & 25.57 \\
\hline $\mathrm{VL}$ & & 0.853 & 0.872 & 12.08 \\
\hline VM & 110 & 0.057 & 0.258 & 14.03 \\
\hline $\mathrm{RF}$ & & 0.869 & -0.033 & 31.43 \\
\hline VL & & 0.564 & 0.948 & 9.09 \\
\hline VM & 120 & 0.916 & 0.788 & 10.01 \\
\hline $\mathrm{RF}$ & & 0.036 & 0.277 & 20.92 \\
\hline VL & & 0.615 & 0.660 & 15.01 \\
\hline VM & 130 & 0.206 & 0.764 & 7.14 \\
\hline $\mathrm{RF}$ & & 0.682 & -1.54 & 43.63 \\
\hline
\end{tabular}

Comparing to T-test, ICC results showed similar results for VL muscle (Table 2). The only joint angle of $80^{\circ}$ and $130^{\circ}$ were slightly below the criterion value of 0.75 which was chosen as the lowest acceptable level of reliability for this study. In other words, VL showed very consistent reliability across the tested range of muscle length. On the other side, VM and $\mathrm{RF}$ differences between two sessions were insignificant in most of the angles in T-test which is not the case with ICC. According to ICC results, VM showed sufficient reliability only at the knee angles of $120^{\circ}$ and $130^{\circ}$ (ICC $=0788$ and 0.764 , respectively), while RF did not show reliability at all in any of tested knee angles. Additionally, results from SEM showed the lowest values right on the knee angles which were reliable either for VL or VM. The highest reliable SEM value found for $\mathrm{VL}$ at the angle of $110^{\circ}$ ( $\mathrm{ICC}=0.867$, $\mathrm{SEM}=12.08)$ and the lowest was at $130^{\circ}$ for $\mathrm{VM}$ (ICC $=0.764$, SEM=7.14) (Table 2). In other words, all reliable ICCs were in range of SEM from 7.14-12.08. Comparing to intra-session $95 \%$ confidence interval for inter-session is slightly but acceptably wider. However, it should be considered when using EMG analysis in testing sessions divided by one week.

\section{DISCUSSION}

\section{Intra-session reliability}

The results of this study showed that intra-session reliability is high for all tested muscles across all joint angles (ICC $=0.795-0.988$ and SEM=1.38-11.71), except RF at $120^{\circ}(\mathrm{ICC}=0.448)$. Similar results for ICC were reported in study that tested within-day reliability in voluntary isometric contraction (ICC $=0.95$ for VL, 0.97 for VM and 0.96 for RF), jump landings (ICC $=0.90$ for VL and VM, and 0.93 for RF) and cuttings with ICC $=0.94$ for VL, 0.88 for VM, and 0.78 
for RF (Fauth et al., 2010). Additionally, Larsson et al (1999) investigated intra-session reliability on 3 sets of 10 dynamic contractions and found high reliability for VL, VM and RF with ICC $=0.89-0.96$ for the mean of ten contractions, and ICC $=0.83-0.97$ for the contractions with the highest peak torque. Moreover, their ANOVA results showed no difference among the sets in both cases, which goes in line with our results that showed insignificant differences between means in 3 consecutive trials in most of the cases. Only two $p$ values in our study (VL and $\mathrm{VM}$ at $110^{\circ}$ ) showed significant differences but followed with high ICC which could be due to small sample size and corresponding big standard deviation. Smith et al (2012) found that intra-session reliability is moderate to high for most of the weight bearing force control conditions that were used. The lowest ICC was 0.34 and highest 0.94 , but the majority of the results was above ICC of 0.75 with corresponding SEMs of not more than 0.20. Intra-session reliability in running for EMG RMS of VL and RF showed good reliability for RF but insufficient for VL with ICC $=0.394$ and 0.794 , followed with SEM of 0.126 and 0.075 or normalized SEM $=34.77$ and 30.18 (Smoliga et al., 2012). It could be due to large standard deviations of the mean which reflects inter-subject variations due to differences in body composition or differences in motor patterns among individuals. (Smoliga et al., 2010). Furthermore, dynamic activity depends on variations in muscle length and shape, and therefore this affects EMG throughout soft tissue filtering since the distance between electrode placement and the active motor unit is cyclically changing (Smoliga et al., 2010).

Even though there are some variations in absolute and relative intra-session reliability results, our and other studies conducted in dynamic and isometric conditions showed high reliability of EMG for RMS between consecutive trails, when the electrodes once positioned had not been moved. When comparing isometric to dynamic contractions of leg extensor muscles, isometric conditions undoubtedly showed high reliability for all three surface heads. In that regard, the first hypothesis of this study has been shown to be true.

\section{Inter-session reliability}

Inter-session reliability is shown be moderate to high for VL at $90^{\circ}, 100^{\circ}, 110^{\circ}, 120^{\circ}$ (ICC $=0.872$ 0.948 with SEM=7.30-9.09, respectively), and moderate for $\mathrm{VM}$ at $120^{\circ}$ and $130^{\circ}(\mathrm{ICC}=0.764$ and 0.788 with SEM=7.14 and 10.01). It was also observed that T-test generally indicated the smallest differences between means of VL compering to VL and RF, which is additional evidence of EMG signal from VL being the most consistent among three tested muscles. The problem with T-test was that it showed non-significant differences between two testing sessions for most of the conditions. More precisely, only RF muscle at one knee angle was shown to have significant differences in means. This could be due to the nature of T-test which measures the straight-line association and not agreement between two measures which is not the appropriate way of estimating reliability (Larsson et al., 2001). That is why this study additionally employed ICC analysis that considers between and within-subject variance for relative reliability, and SEM for the absolute reliability which is determined from standard deviation of the scores from all subjects and ICC reliability coefficient (Larsson et al., 2003; Mathur et al., 2005; Wier, 2005).

Knee angle of $120^{\circ}$ of showed highest reliability values for VL and VM while lengthening the muscle further resulted in lowered reliability levels for VM and lack of reliability for VL. Rectus femoris did not show reliable activation on any of tested angles. Mathur et al. (2005) reported day to day reliability to be low to very high (ICC $=0.68$ for VL, 0.88 for VM, and 0.91 for RF) during sustained contraction of $20 \%$ of MVC. They also reported a decreased level of reliability for RF and increased for VL, when the contraction intensity was set to $80 \%$ of MVC (ICC $=0.66$ for RF, 0.83 for $\mathrm{VM}$, and 0.84 for $\mathrm{VL}$ ). This was explained by the inverse correlation between force production and force variability - higher force shows higher within-subject variability which may affect day to day reliability (Mathur et al., 2005). In the study of Larsson et al. (2003), the results showed lack of reliability of three surface quadriceps heads when the RMS signal was normalized (ICC=-0.02 for VM, 0.43 for RF and 0.52 for VL). Even it was very low, normalized EMG reliability for VL in this study was higher than for VM and RF (Larsson et al., 2003). However, protocol in this study consisted of 100 dynamic movements where electrode position could be compromised, and it cannot be certain if the activation from the same motor units were recorded in every consecutive contraction. Also, authors used different normalization method which, as they said, should be further investigated (Larsson et al., 2003). Rainoldi et al (2001) reported similar results as ours. They used knee angle of 
$130^{\circ}$ for isometric contraction and for amplitude variable only VL showed reliable activation. The probable cause for lack of repeatability of the activation pattern in VM could lie in the muscle fibre length, in the portion of VM where the electrode should be placed. Vastus medialis oblique is a small part of the VM close to the knee, and those fibres are short. Thus, day to day placement could influence the signal obtained (Rainoldi et al., 2001). The overlapping of the actin and myosin filaments seem to be the most optimal on these muscle lengths as well as the angle of the muscle attachment to the bone. Thus, Golgi tendon organ will not be neither excited nor inhibited. Furthermore, joint surfaces are in such position, so there is no high intra-articular pressure and anterior cruciate ligament is relatively relaxed which again removes excitation and inhibition reflexes that could influence the muscle activation (Gandevia \& McKenzie, 1998; McGinty et al., 2000). It could be concluded that these knee joint angles might be the best positions for the acquisition of the EMG signal in quadriceps testing when the leg extension is planned to be used. These muscle lengths allow maximal muscle activation while other factors are minimalized.

Standard Error of Measurement has frequently been used as a measure of absolute reliability (Larsson et al., 2003; Campy et al., 2009; Mathur et al., 2005; Smith et al., 2012). Results of Larsson et al (2003) were very different after they normalized EMG signal. When RMS was expressed in $\mu \mathrm{V}$, RF, $\mathrm{VM}$ and VL showed high reliability (ICC $=0.89$ for RF, 0.88 for VM and 0.83 for VL) but the SEM values were very high (SEM=49, 49, 63). In other words, relative reliability was high but absolute was low. On the other side, when RMS was normalized, ICC showed lack of reliability with VL having the highest ICC, but the SEM values were much lower (SEM=17 for RF, 19 for VM, and 16 for VL). Campy et al (2009) conducted the inter-session reliability for medial and lateral hamstring muscles at different contraction intensities. For every intensity that showed reliable results (ICC $=0.77-0.92$ ), SEM values were below 14 (SEM=9.72-13.57). Comparing to mentioned study, our results showed better relative reliability followed with the low corresponding absolute measure of reliability as well. Furthermore, results of Mathur et al (2005) suggest that $80 \%$ MVC contraction intensity could be a better choice than 20\% MVC for EMG investigations because relative reliability was similar for both intensities, but SEM showed better absolute reliability at $80 \%$ MVC. Even though ICC for RF at $20 \%$ MVC was higher, its SEM was lower as well as VM's and VL's SEM values (9.8-17.2 for $80 \%$ MVC vs 14.8-22 for 20\% VMC) (Mathur et al., 2005). Note that most of the moderate to high ICC values were followed by SEM values less than 15, which is also the case in our study. Thus, this might be the evidence of the good validity of the approach and precision of the electrode placement.

It cannot be assumed that two muscles within a region or similar function will be equally reliable. The same holds true for the knee extensor muscles, namely with the VL being more reliable in RMS than other two tested muscles. However, VM also showed good reliability on $120^{\circ}$ and $130^{\circ}$ of knee joint angle. The discrepancy between reliable and non-reliable muscles could be due to consistency of muscle activation patterns between muscles crossing one joint versus the one crossing two joints. Comparing to the VL and $\mathrm{VM}, \mathrm{RF}$ is a two-joint muscle which could cause the redundancy of the muscle activation in non-specific contraction conditions, and increased redundancy lowers the reliability. Contrary, natural pattern of the $\mathrm{RF}$ requires the adjustment of its activation in accordance with the hip-knee relation, and RF has been shown to doing it very reliably (Mathur et al., 2005; Stensdotter et al., 2003; Larsson et al., 2003; Smoliga et al., 2010). According to mentioned above, the conclusion could be made that inter-session reliability of normalized EMG RMS from MVIC is subject to various factors such as sample size, type of contraction, number of joints included, statistics used, and muscle length.

\section{CONCLUSION}

Our study dealt with the effect of muscle length on reliability, and the conclusion could be made that reliability between consecutive trails is not affected by the change of muscle length in any tested muscle. On the other side, when the testing sessions are divided by 7-8 days, change in muscle length does affect the reliability of both, single-joint and multi-joint muscles of quadriceps femoris during leg extension. Furthermore, the most reliable surface head of quadriceps femoris is shown to be vastus lateralis followed by vastus medialis, while rectus femoris did not show any reliability in activation. Thus, the second hypothesis of this study is also proved to be true because the 
reliability of all tested muscles was affected by knee angle and VL was the most reliable among the tested muscles. Additionally, the angle of $120^{\circ}$ of knee extension is shown to be the only angle reliable for both $\mathrm{VL}$ and VM which suggests that this angle might be a good choice for the leg extension testing if it includes MVIC and EMG.

This study was a short experimental investigation of possible methodological issues when electromyography is used in leg extension MVIC at different knee angles, and 2 practical advices could be made: 1) RF can be excluded due to lack of reliability; 2) If EMG RMS from VL and VM will be tested, knee angle of $120^{\circ}$ should be used for the testing.

\section{LIMITATIONS}

Certain methodological limitations could influence the applicability of the results. The sample of the subjects was clustered which means participants were chosen by their physical ability to do the test. The age range of participants was very small, and the sample included only male participants, so the application of the results to older population or female population is not possible. All participants of this study were very fit with very low amount fat tissue, so application to

\section{REFERENCES}

1. Ball, N., \& Scurr, J. (2010). An assessment of the reliability and standardisation of tests used to elicit reference muscular actions for electromyographical normalisation. Journal of Electromyography and Kinesiology, 20(1), 81-88.

2. Burden, A. (2010). How should we normalize electromyograms obtained from healthy participants? What we have learned from over 25years of research. Journal of Electromyography and Kinesiology, 20(6), 1023-1035.

3. Burnett, A., Green, J., Netto, K., \& Rodrigues, J. (2007). Examination of EMG normalisation methods for the study of the posterior and posterolateral neck muscles in healthy controls. Journal of Electromyography and Kinesiology, 17(5), 635-641.

4. Campy, R. M., Coelho, A. J., \& Pincivero, D. M. (2009). EMG-torque relationship and reliability of the medial and lateral hamstring muscles. Medicine and Science in Sports and Exercise, 41(11), 20642071. more fatty or obese participants is questionable. This test with MVIC could not be conducted with the population that has any medical condition of the knee joint.

\section{ACKNOWLEDGEMENTS}

This study is part of the Master Degree Thesis: Reliability of EMG signal during maximal isometric contraction of quadriceps femoris at different muscle lengths in open and closed kinetic chain, Belgrade, Serbia, Faculty of Sport and Physical Education, University of Belgrade.

This research is part of the project Effects of applied physical activity on the locomotor, the metabolic, psychosocial and educational status of the population of the Republic of Serbia, under number III47015 and 41007, which is financed by Ministry of Education and Science of the Republic of Serbia - Cycle of Projects 2011-2016.

We would like to thank to Serbian Institute of Sport and Sports Medicine for granting us the use of their laboratory for physical assessment. Also, special thanks to Profex Academy of Healthy Living for allowing us to use their Delsys EMG system.

5. Dankaerts, W., O'Sullivan, P. B., Burnett, A. F., Straker, L. M., \& Danneels, L. A. (2004). Reliability of EMG measurements for trunk muscles during maximal and sub-maximal voluntary isometric contractions in healthy controls and CLBP patients. Journal of Electromyography and Kinesiology, 14(3), 333-342.

6. De Luca, C. J. (1997). The use of surface electromyography in biomechanics. Journal of Applied Biomechanics, 13(2), 135-163.

7. De Luca, C. J. (2002). Surface electromyography: Detection and recording. DelSys Incorporated, 10.

8. Enoka, R. M., \& Duchateau, J. (2015). Inappropriate interpretation of surface EMG signals and muscle fiber characteristics impedes understanding of the control of neuromuscular function. Journal of Applied Physiology, 119(12), 1516-8.

9. Farina, D., Merletti, R., \& Enoka, R. M. (2014). The extraction of neural strategies from the surface EMG: an update. Journal of Applied Physiolo- 
gy, 117(11), 1215-1230.

10. Fauth, M. L., Petushek, E. J., Feldmann, C. R., Hsu, B. E., Garceau, L. R., Lutsch, B. N., \& Ebben, W. P. (2010). Reliability of surface electromyography during maximal voluntary isometric contractions, jump landings, and cutting. The Journal of Strength \& Conditioning Research, 24(4), 11311137.

11. Gandevia, S. C., \& McKenzie, D. K. (1988). Activation of human muscles at short muscle lengths during maximal static efforts. The Journal of Physiology, 407(1), 599-613.

12. Hopkins, W. (2000). Measures of Reliability in Sports Medicine and Science. Sports Medicine, 30(1), 1-15).

13. Larsson, B., Karlsson, S., Eriksson, M., \& Gerdle, B. (2003). Test-retest reliability of EMG and peak torque during repetitive maximum concentric knee extensions. Journal of Electromyography and Kinesiology, 13(3), 281-287.

14. Larsson, B., Månsson, B., Karlberg, C., Syvertsson, P., Elert, J., \& Gerdle, B. (1999). Reproducibility of surface EMG variables and peak torque during three sets of ten dynamic contractions. Journal of Electromyography and Kinesiology, 9(5), 351-357.

15. Mathur, S., Eng, J. J., \& MacIntyre, D. L. (2005). Reliability of surface EMG during sustained contractions of the quadriceps. Journal of Electromyography and Kinesiology, 15(1), 102-110.

16. McGinty, G., Irrgang, J. J., \& Pezzullo, D. (2000). Biomechanical considerations for rehabilitation of the knee. Clinical biomechanics, 15(3), 160-166.

17. Merletti, R., \& Di Torino, P. (1999). Standards for reporting EMG data. Journal of Electromyography and Kinesiology, 9(1), 3-4.

18. Mirka, G. A. (1991). The quantification of EMG normalization error. Ergonomics, 34(3), 343-352.
19. Rainoldi, A., Bullock-Saxton, J. E., Cavarretta, F., \& Hogan, N. (2001). Repeatability of maximal voluntary force and of surface EMG variables during voluntary isometric contraction of quadriceps muscles in healthy subjects. Journal of Electromyography and Kinesiology, 11(6), 425-438.

20. Smith, A. J., Flaxman, T. E., Speirs, A. D., \& Benoit, D. L. (2012). Reliability of knee joint muscle activity during weight bearing force control. Journal of Electromyography and Kinesiology, 22(6), 914-922.

21. Smoliga, J. M., Myers, J. B., Redfern, M. S., \& Lephart, S. M. (2010). Reliability and precision of EMG in leg, torso, and arm muscles during running. Journal of Electromyography and Kinesiology, 20(1), e1-e9.

22. Stensdotter, A. K., Hodges, P., Mellor, R., Sundelin, G., \& Häger-Ross, C. (2003). Quadriceps activation in closed and in open kinetic chain exercise. Medicine and Science in Sports and Exercise, 35(12), 2043-2047.

23. Wang, L., \& Buchanan, T. S. (2002). Prediction of joint moments using a neural network model of muscle activations from EMG signals. IEEE Transactions on Neural Systems and Rehabilitation Engineering, 10(1), 30-37.

24. Weir, J. P. (2005). Quantifying test-retest reliability using the intraclass correlation coefficient and the SEM. Journal of strength and conditioning research, 19(1), 231-240.

25. Worrell, T. W., Crisp, E., \& Larosa, C. (1998). Electromyographic reliability and analysis of selected lower extremity muscles during lateral step-up conditions. Journal of Athletic Training, 33(2), 156-162. 


\title{
ZUVERLÄSSIGKEIT DER ELEKTROMYOGRAFIE WÄHREND UND ZWISCHEN SETS BEI MAXIMALEN ISOMETRISCHEN KONTRAKTIONEN DES QUADRIZEPS: EINFLUSS DES GELENKWINKELS
}

\begin{abstract}
Zusammenfassung:
Verschiedene Faktoren können Einfluss auf die Zuverlässigkeit von elektromyographischen Signalen (electromyography - EMG) ausüben, von welchen die Art der Kontraktion praktisch die wichtigste ist. Ziel dieser Studie ist es, die Zuverlässigkeit der EMG während einer maximalen Kontraktion (maximal voluntary contraction - MVC) von Extensormuskeln im Kniegelenk bei verschiedenen Gelenkwinkeln im Rahmen eines oder zwischen zwei Sets festzulegen. Neun gesunde, körperlich gut vorbereitete Studenten der Fakultät für Sport und Körperkultur haben auf freiwilliger Basis an diesem Test teilgenommen. Die Grundcharakteristiken der Prüflinge waren: 23+/- 1 Jahr, Körpermasse $80.8+/-7.8 \mathrm{~kg}$ und Körpergröße 182+/-7 cm. Analysiert wurde das EMG-Signal mit 3 unterschiedlichen Köpfen des Musculus quadriceps femoris: äußerer Kopf (VL), innerer Kopf (VM) und gerader Kopf (RF). Die Prüflinge hatten die Aufgabe, 3 möglichst schnelle und möglichst intensive MVC in 6 unterschiedlichen Ausgangswinkeln im Kniegelenk in 2 Sets durchzuführen, die 7 - 8 Tage voneinader lagen. Das statistische intra - class - coefficient - of - correlation - Verfahren (ICC) wurde verwendet, um die relative Zuverlässigkeit auf Ebene des Sets selbst und zwischen den Sets festzustellen, während das standard - error - of - measurement - Verfahren (SEM) angewendet wurde, um die absolute Zuverlässigkeit jedes getesteten Muskels auszurechnen. Alle Muskeln wiesen eine hohe Zuverlässigkeit im Rahmen des gleichen Sets vor (ICC=0.488-0.988 und SEM=1.38-11.35). VL wies eine gute Zuverlässigkeit zwischen den Sets für die Mehrheit der Ausgangsbedingungen (ICC $=0.603-0.948$ ) vor, VM für zwei Gelenkwinkel (ICC120 $=0.764$ und $\mathrm{ICC} 130^{\circ}=0.788$ ), RF zeigte für keinen der Ausgangswinkel im Kniegelenk Zuverlässigkeit. Diese Studie weist darauf hin, dass RF wegen einem Mangel an Zuverlässigkeit zwischen zwei Sets nicht für EMG-Tests während MVC bei einer Beinextension geeignet ist und und dass der Winkel von $120^{\circ}$ bei EMG RMS Tests für VM und VL angewendet werden sollte.
\end{abstract}

Schlüsselwörter: TEST / ZUVERLÄSSIGKEIT / SET ZWISCHEN 7-8 TAGEN / / SET IM LAUFE VON EINEM TAG

Received: 01.03. 2017

Accepted: 06.11.2017 


\title{
ПОУЗДАНОСТ ЕЛЕКТРОМИОГРАФИЈЕ УНУТАР И ИЗМЕБУ СЕСИЈА ПРИ МАКСИМАЛНИМ ВОЉНИМ ИЗОМЕТРИЈСКИМ КОНТРАКЦИЈАМА КВАДРИСЕПСА: УТИЦАЈ ЗГЛОБНОГ УГЛА
}

\author{
Филип Кукић ${ }^{1}$, Александар Станковић³, Владимир Мрдаковић ${ }^{2}$, Душко Илић², Милош Убовић \\ ${ }^{1}$ Одјељење за стратешки менаџмент и побољшање перформанси, Полиција Абу Дабиа, Уједињени Арапски Емирати \\ ${ }^{2}$ Универзитет у Београду, Факултет спорта и физичког васпитања, Србија \\ ${ }^{3}$ Профекс, Академија здравог живота, Београд, Србија
}

\begin{abstract}
Сажетак
Различити фактори могу утицати на поузданост електромиографског сигнала (electromyography - EMG), од којих је врста контракције практично најважнија. Ова студија има за циљ да истражи поузданост ЕМГ током максималне вољне контракције (maximal voluntary contraction - MVC) мишића екстензора у зглобу колена при различитим зглобним угловима унутар исте или између две сесије. Девет здравих, физички добро припремљених, студената Факултета спорта и физичког васпитања су добровољно приступили тестирању. Основне карактеристике испитаника су биле: $23 \pm 1$ година, телесна маса $80.8 \pm 7.8 \mathrm{~kg}$ и телесна висина $182 \pm 7 \mathrm{~cm}$. Анализиран је EMG сигнал са 3 различите главе m.quadriceps femoris-a: спољашња глава (VL), унутрашња глава (VM) и права глава (RF). Испитаници су имали задатак да спроведу 3 што брже и што јаче MVC у 6 различитих почетних углова у зглобу колена у 2 сесије одвојене 7-8 дана. Статистичка процедура intra-class coefficient of correlation (ICC) је коришћена како би се идентификовала релативна поузданост на нивоу саме сесије и између сесија, док је standard error of measurement (SEM) коришћена како би се израчунала апсолутна поузданост сваког тестираног мишића. Сви мишићи су показали високу поузданост унутар исте сесије (ICC=0.488-0.988 и SEM=1.38-11.35). $\mathrm{VL}$ је показао добру поузданост између сесија за већину почетних услова (ICC=0.603-0.948), VM за два зглобна угла $\left(\mathrm{ICC} 120^{\circ}=0.764\right.$ и ICC $\left.130^{\circ}=0.788\right), \mathrm{RF}$ није био поуздан ни за један почетни угао у зглобу колена. Ова студија показује да RF не би требало користити у EMG тестирањима током MVC при екстензији ногу због недостатка поузданости између све сесије, и да би угао од $120^{\circ}$ трељало да се користи при EMG RMS тестирању VM и VL.
\end{abstract}

КљУчне речи: ТЕСТИРАЮЕ / ПОУЗДАНОСТ / СЕСИЈА ИЗМЕЂУ 7-8 ДАНА / СЕСИЈА УНУТАР ЈЕДНОГ ДАНА

\section{УВОД}

Површински електромиографски сигнал (electromyography - EMG) представља нервну активацију моторне јединице снимљену на површини мишића. Активација моторне јединце доводи до контракције сваког мишићног влакна инервисаног том јединицом, што даље доводи до испољавања мишићне силе. Штавише, мишићна сила је делимично резултат суме сигнала и временске шеме активације моторних јединица (Wang и Butchman, 2002; Farina et al., 2014; Enoka и Duchateau, 2015). Многи спољашњи и унутрашњи фактори могу утицати на квалитет EMG сигнала: грешке у техници, грешке у опреми, ефекат учења, биолошке варијације (Ball и Scurr, 2010; Burden, 2010; De Luca, 1997; Larsson, 2003). Да би се превазишли неки од фактора и како би се омогућило поређење EMG сигнала између различитих мишића и различитих тестирања, сигнал би требало нормализовати (Mirka, 1991; Burnett et al., 2007; Dankaerts et al., 2005). Пошто мишићна активација варира са променом зглобног угла, поређење EMG сигнала у различитим мишићним дужинама би требало радити са нормализованим сигналом који представља релативизовани ниво мишићне активације (Mirka, 1991; Merletti et al 1999). У односу на практичну применљивост, 
коришћење метода нормализације је неопходно за процену поузданости EMG сигнала.

У скорашњим истраживањима, коришћени су различити приступи испитивању поузданости сигнала. Најчешће је поузданост испитивана за различите интензитете (Campy et al., 2009; Larsson et al, 2003; Mathur et al, 2005; Rainoldi et al, 2001; Smith et al, 2012). Кампи и сарадници (2009) су испитивали мишиће задње ложе натколенице током различитих интензитета контракције и пронашли високи коефицијент поузданости за случај тест-ретест (ICC $=0.70-0.92$ и $\mathrm{SEM}=9.72$ $24.94 \%)$, само за унутрашње мишиће задње ложе за малу до умерено интензивну изометријску контракцију - 10-60\% од максималне вољне контракције (maximal voluntary contraction - MVC). У истој студији, спољашњи мишићи задње ложе су показали умерени коефицијент поузданости (ICC $=0.57-0.68$ и SEM=13.12-21.35\%), само на малим интензитетима контракције - 10-30\% од MVC (Campy et al, 2009). Још једна студија је показала високу поузданост (ICC=0.80-0.95 и SEM=969) за мишиће екстензоре током 100 динамичких максималних опружања десног колена у две сесије одвојене 7-8 дана (Larsson et al, 2003). Матур и сарадници (2005) су испитивали поузданост средње фреквенције и амлитуде EMG на $80 \%$ и $20 \%$ од максималне вољне контракције задржане до потпуне исцрпљености. За обе варијабле, средњу фреквенцију и амплитуду, иницијални, крајњи и нормализовани EMG су показали умерену до високу поузданост за спољашњи вастус (vastus lateralis - VL), унутрашњи вастус (vastus medialis $V M)$ и прави мишић бута (rectus femroris - RF) за оба нивоа контракције: $I C C=0.59-0.88$ за MDF; ICC $=0.58-0.99$ амплитуде (Mathur и cap., 2005). У сличној студији, Раинолди и сарадници (2001), су пронашли висок ниво поузданости (ICC>70\%) током 50 секунди одржавања контракције na 50\% MVC. У weight-bearing студији, Смит и сарадници (2012), утврђују високу поузданост између сесија за мерење активности квадрицепса у већини испитаних услова, ICC=0.60-0.94. У истој студији аутори су пронашли сличне резултате за поузданост унутар сесија, где је ICС била 0.63-0.95.

Када је реч о поузданости унутар исте сесије, многе студије показују умерени до високи степен поузданости, у зависности од постављеног задатка (Larsson et al., 1999; Fauth et al., 2010, Smoliga et al., 2010; Smith; 2012; Worrel et al., 1998). Ларсон и сарадници (1999) су истраживали поузданост унутар истог дана, користећи протокол од 10 максималних динамичких опружања ноге са паузом од једног сата. Они су пратили EMG сигнал за VL, $\mathrm{RF}$ и $\mathrm{VM}$ и резултати су показали висок ниво поузданости за све мишиће, ICC=0.83-0.98, али је VL био најпоузданији (Larsson et al, 1999). Још једна студија поузданости подразумевала је 3 различита задатка: максималну вољну изометријску контракцију (maximal voluntary isometric contraction - MVIC), скок са висине и промену правца, поузданост EMG сигнала је била јако висока, уз све ICC вредности веће од 0.80 (Fauth et al, 2005). Смолига и сар. (2010) су испитивали поузданост EMG код професионалних тркача. Израчунали су ICC за 25 везаних корака и пронашли ICC $>0.80$ за 7 од 13 тестираних мишића, где cy VL и RF имали ICC $<0.80$, где је RF имао већу поузданост од VL: ICC за RF=0.794 и ICC за VL=0.394 (Smoliga et al., 2010). У студији са бочним кораком на платформу, Ворел и сарадници. (1998) су пронашли високу поузданост унутар сесија са ICC вредностима од 0.89-0.98 за VM и за VL од 0.67-0.99 за мишиће задње ложе натколенице и глутеуса. Са друге стране, у истој студији је пронађена мала до умерена поузданост између сесија са ICС вредностима од 0.06-0.67 и 0.34-83 за исте мишићне групе (Worrel et al 1998).

У само 2 од претходно наведених 9 студија истраживачи су се бавили поузданошћу и унутар и између сесија (Worrel et al, 1998; Smith et al, 2012) и имали су другачије резултате. Оба истраживања су показала добру EMG поузданост унутар сесије, али је једна студија показала малу до умерену EMG поузданост између сесија (Worrel et al, 1998), док је друга показала умерено до високу EMG поузданост између сесија (Smith et al, 2012). Чини се да постоји одређени број истраживања која објашњавају различиту EMG поузданост у зависности од дизајна истраживања и постављених задатака. Ипак, према нашем сазнању, постоји недостатак доказа у погледу поузданости за базичну релацију између мишићне активације и мишићне дужине (electromyography-length relationship, EMG-l) током MVIC. Такође, не постоји много студија које се баве са обе повезаности, и унутар сесија и између сесија, уз неконзистентност добијених резултата. Према томе, неопходно је прикупити још важних података. Из тог разлога, сврха овог истраживања је била да се испитају ефекти про- 
мене угла у зглобу колена на EMG поузданост током MVIC на нивоу саме сесије - између два узастопна покушаја, као и између сесија - између два тестирања. Две хипотезе ће бити тестиране: 1) на нивоу саме сесије ће се показати висока поузданост за све зглобне углове и испитане мишиће; 2) поузданост између сесија ће показати умерен до висок ниво, у зависности од угла у зглобу колена и испитаног мишића, где ће VL показати највећу поузданост.

\section{МЕТОДЕ}

Будући да је узорак испитаника за студији чинило девет учесника и да су спроведена два тестирања, ова студија представља пилот-студију спроведену по лабораторијским принципима и коришћењем одабраног узорка (Hopkins, 2000).

\section{Испитаници}

Девет здравих студената мушког пола са Факултета спорта и физичког васпитања добровољно се прикључило експерименту. Основне карактеристике испитаника биле су: старост $23 \pm 1$ година, телесна маса $80.8 \pm 7.8$ килограма и висина $182 \pm 7$ центиметара.

Последње три године сви испитаници су били укључени у физичку активност минимум три пута недељно. Није било показатеља било какве повреде колена или неуролошких поремећаја у њиховој здравственој историји. Сви испитаници су били информисани о сврси студије и могли су да напусте студију у сваком тренутку. Студију је одобрио Етички комитет Факултета спорта и физичког васпитања у складу са Хелсиншком декларацијом о истраживањима на људским субјектима.

\section{Мерење}

\section{Постављање електрода}

Мерен је EMG сигнал са три површинске главе m.quadriceps femoris-a: VL, VM, и RF користећи појединачне површинске EMG електроде компаније Делсис (Delsys Ink., Boston, MA). Електроде су постављене по приручнику произвођача (Delsys technical note 101: EMG sensor placement). Уземљење је постављено на зглоб кука супротне ноге. Кожа је обријана на месту на ком је електрода постављена, очишћена алкохолом и намазана гелом за ултразвук ради боље електричне проводљивости. Електроде су постављене на најистакнутије место мишићног трбуха према Делсисовом приручнику (De Luca, 2002). Позиције електрода су означене на кожи водоотпорним маркером како би се позиција могла пратити из дана у дан. Како би се избегао шум, електроде су постављене на најмање три центиметра једна од друге и чврсто фиксиране медицинском траком око ноге и преко електрода, тако да су електроде биле непомичне. Додатне траке су коришћене како би се фиксирали каблови електрода.

\section{Прикупљање и обрада EMG сигнала}

Појединачно вишеканално EMG појачало од $1000 \mathrm{~Hz}$ је коришћено како би се регистровао EMG сигнал. Фреквенција узорковања је била $2000 \mathrm{~Hz}$, и A/D конвертована са дванаесто-битном прецизношћу у опсегу напона од $\pm 0.002 \mathrm{~V}$.

Оригиналан Делсисов софтвер (Delsys EMG works 4.1) је коришћен за обраду сигнала. Како би се проценио ниво мишићне активности, за рачунање је коришћен корен средњег квадрата (root mean square - RMS). Према Де Луки (De Luca, 1997), RMS је мерило снаге EMG сигнала. Трајање исечка је било $100 \mathrm{~ms}$ ca $80 \mathrm{~ms}$ преклапања између исечака. За даљу статистичку анализу, прве две секунде сваке контракције су биле нормализоване у односу на највећи MVC. Почетак контракције је праћен четвртим каналом који је био повезан са мерачом промене напона (Foot switcher). Foot switcher jе био постављан на предњу ивицу тибије, у нивоу контакта тибије са полугом динамометра. Мерена је промена у напону изазвана притиском тибије на полугу, што је представљало почетак контракције.

\section{Упознавање са поступком и поставка тестирања}

Испитаници су дошли у лабораторију два пута: недељу дана пре првог дана тестирања, а затим три дана пре првог дана тестирања како би се упознали са процедурама. Прво упознавање са тестирањем је искоришћено како би се поставила изокинетичка столица (Kin-Com, Chattanooga Group, Inc. Chattanooga TN) према антропометријским карактеристикама испитаника и како би се испитаник упознао са режимом мишићне контракције. Позиција натколенице у односу на хоризонталу је фиксирана за све учеснике, док су потпора за леђа и цела столица подешени како би 
се фиксирао зглоб кука у позицији од 90 степени. Оса ротације динамометра и оса ротације зглоба колена су поравнате померањем главе динамометра. Исти принцип је коришћен и за паралелно поравнање полуге динамометра и тибије. Два одвојена каиша су коришћена како би се горњи део тела фиксирао за столицу, један који је фиксирао кукове за столицу и други који је фиксирао натколеницу за столицу. Систем за детекцију силе је постављен један центиметар изнад спољашњег глежња потколенице (malleolus lateralis-a). Позиција столице за сваки зглоб колена је означена и записана. Коришћењем исте позиције столице за оба дана тестирања, могућност техничке грешке, приликом мерења, сведена је на минимум. Друга сесија за упознавање са процедуром је коришћена само како би се обезбедило још боље навикавање са режимом мишићне контракције и за обележавање позиција за постављање електрода.

\section{Процедура мерења}

Сви испитаници су се пре мерења загрејали по следећем протоколу - 10 минута вожње бицикл ергометра, а затим су се 3-5 минута динамички истезали. Након истезања електроде су позициониране и са фиксираним електродама испитаници су постављени у већ за сваког припремљену динамометарску столицу. Испитаници су морали да изведу три MVIC најбрже и најјаче што су могли у шест различитих, насумично изабраних углова зглоба колена. Тестирани углови су износили $80^{\circ}$, $90^{\circ}, 100^{\circ}, 110^{\circ}, 120^{\circ}$, и $130^{\circ}$ екстензије колена (угао између фемура и тибије). Трајање сваке контракције је било три секунде. Период одмора између контракција је био 45-60s. Након што је завршено мерење у тесту при једном зглобном углу, испитаници су 3-5 минута одмарали. За то време мериоци су постављали услове за мерење при другом зглобном углу. Прецизност контракције је контролисана испољеном силом. Свака контракција, у којој је изведен циклус истезање-скраћење или која је трајала краће од три секунде је поновљена, све док нису забележене три успешне контракције. Како би могли да дају свој максимум у свакој контракцији, испитаници су на екрану могли да прате график у испољеној сили. Такође, за бољу мотивацију, били су подржани од стране тима за тестирање. Идентични протокол са истим редоследом углова у зглобу колена је био спроведен у обе сесије тестирања.

\section{Статистичка анализа}

Све RMS вредности су унете у Мајкрософт Ексел (Microsoft Excel) ради даље анализе. Дескриптивна статистика за средњу вредност и стандардну девијацију је извршена у Мајкрософт Екселу. За процену поузданости, коришћен је софтвер SPSS Statistics 17. Међукласни коефицијент корелације са интервалом поузданости од 95\% (ICC ${ }_{2,1}$ two-way random effect) је коришћен како би се идентификовала поузданост тестирања и у истом и у различитим данима тестирања (Larsson et al, 2003), користећи ниво значајности од $p<0.05$. ICC је изабран за меру релативне поузданости јер узима у обзир варијације како између испитаника, тако и варијације самих испитаника (Larsson et al, 2003; Mathur et al, 2005; Wier, 2005). ICС вредности веће од 0.75 представљају високу поузданост, вредности од 0.60-0.74 представљају умерену поузданост, а ниску поузданост или мањак поузданости би чиниле све вредности испод 0.60 (Smith et al, 2012). У складу са претходном студијом (Dankaerts et al, 2004), за прихватљив ниво поузданости узета је вредност од 0.75. Понекад може да се појави негативан ICC што значи да варијације појединих испитаника премашују варијације између испитаника (Larsson et al, 2003; Rainoldi et al, 2001). Baријабилност међу субјектима мора бити значајна. Ако то није случај, ограничења ICC не одговарају теоретским лимитима од 0.0-1.0, и не могу бити сматрана валидним. Практично, могуће је да се опсези крећу од негативне до позитивне бесконачности. У том случају, алтернативна мера за поузданост - стандардна грешка мерења (standard error of measurement - SEM) - је коришћена како би изразила апсолутну поузданост мерења (Smith et al, 2012). Будући да су постојале две сесије тестирања и три покушаја за сваки угао колена, додатно је коришћен Т-тест за упарене узорке како би се утврдило да ли постоје статистички значајне разлике у нормализованим вредностима EMG-а између сесија (Smith et al, 2012). Једнофакторска анализа варијансе (One-way ANOVA) је коришћена како би се тестирале разлике између три покушаја (Larsson et al, 1999). У обе статистичке анализе коришћен је $a<0.05$ ниво статистичке значајности. SEM је коришћена како би се израчунала апсолутна поузданост између две сесије тестирања и детерминисана је на основу стандардне девијације резултата. Што је мањи SEM, бољи је резултат (Wier, 2005; Mathur et al, 2005). 


\section{РЕЗУЛТАТИ}

Дескриптивна статистика показује разлике између средњих вредности тест-ретеста и стандардних девијација нормализованог EMG сигнала за сваки тестирани мишић. Графици 1-3 показују да
VL има најмање разлике између две сесије тестирања у поређењу са друга два тестирана мишића. Најмање разлике код VM су се догодиле када је угао колена био $120^{\circ}$ и $130^{\circ}$ (График 2). Код RF ce чини да само угао колена од $110^{\circ}$ има малу разлику између средњих вредности (График 3 ).

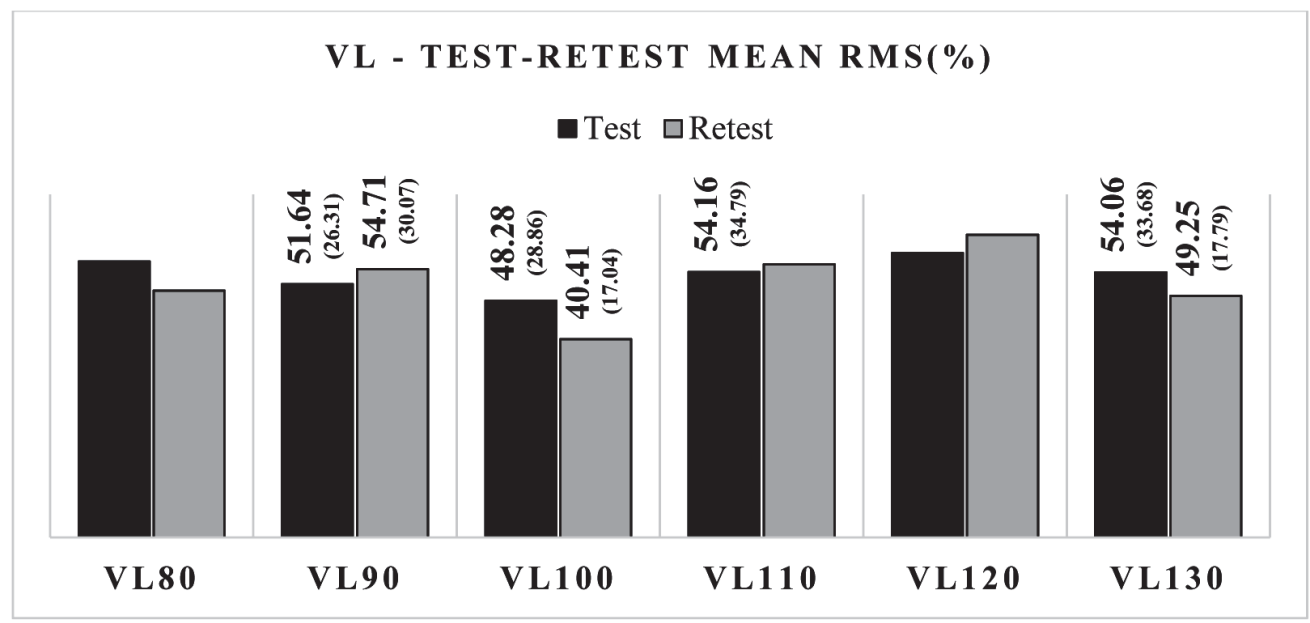

Слика 1. Дескриптивна статистика за средње вредности и стандардну девијацију за обе сесије за $V L$.

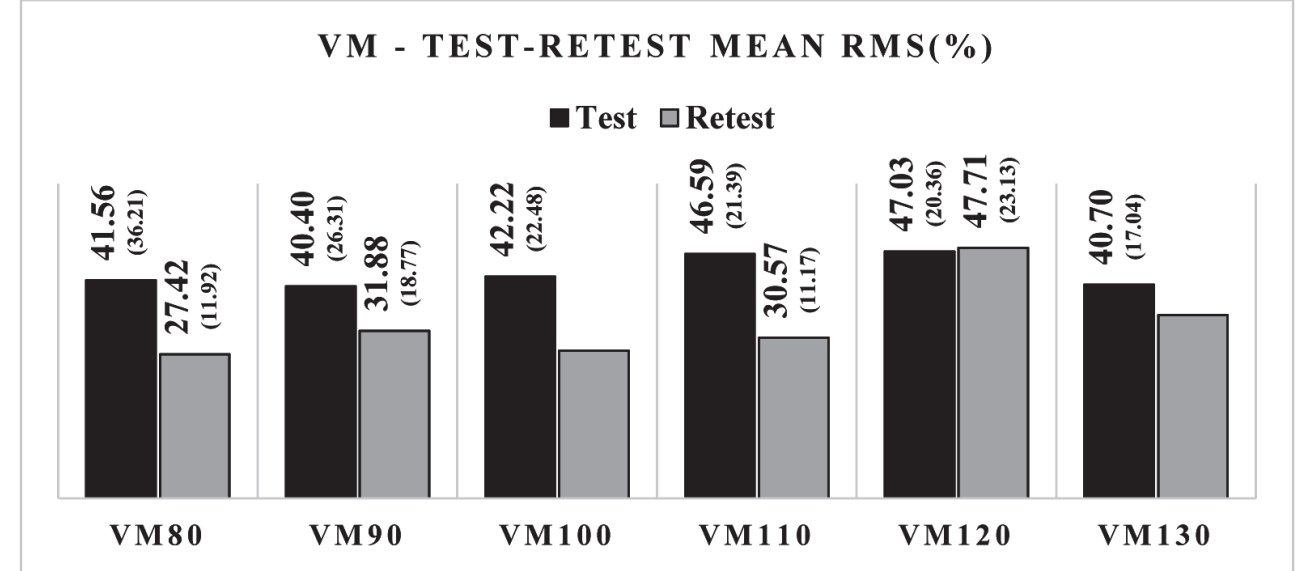

Слика 2. Дескриптивна статистика за средње вредности и стандардну девијацију за обе сесије за $V M$.

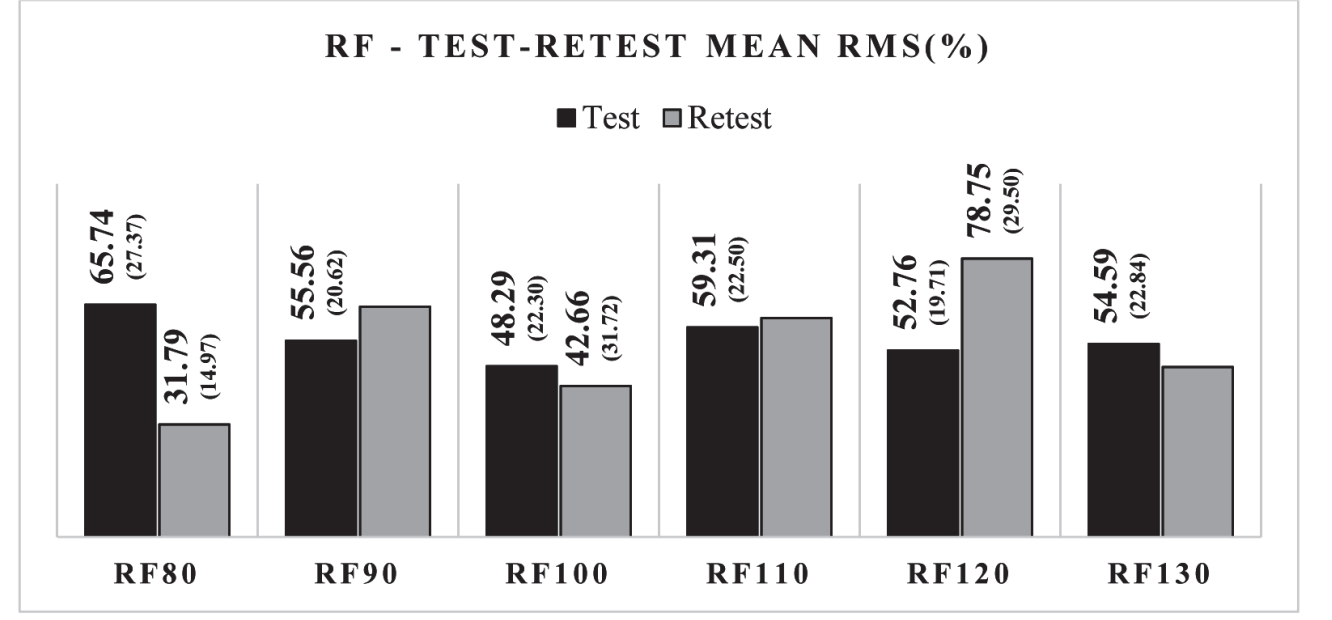

Слика 3. Дескриптивна статистика за средње вредности и стандардну девијацију за обе сесије за $R F$. 


\section{Поузданост унутар сесије}

Табела 1 показује резултате апсолутне и релативне поузданости између три узастопна покушаја унутар сесије. ANOVA је показала значајне разлике између средњих вредности само код VL и VM када је угао колена $110^{\circ}$ ( $\mathrm{Sig}=0.021$ за VL и 0.011 за VM). Резултати за све остале измерене углове за сваки мишић нису показали никакву значајну разлику у средњим вредностима између покушаја.

Табела 1. Статистика поузданости унутар сесије за све испитане мишиће и углове у зглобу колена

\begin{tabular}{lcccc}
\hline \multicolumn{1}{c}{ Muscle } & $\begin{array}{c}\text { Knee } \\
\text { angle }\end{array}$ & $\begin{array}{c}\text { ANOVA } \\
\text { Sig }\end{array}$ & ICC & SEM \\
\hline VL & & 0.546 & 0.975 & 5.32 \\
VM & 80 & 0.898 & 0.976 & 1.85 \\
RF & & 0.253 & 0.956 & 5.26 \\
\hline VL & & 0.684 & 0.979 & 6.64 \\
VM & 90 & 0.546 & 0.970 & 2.20 \\
RF & & 0.793 & 0.962 & 2.99 \\
\hline VL & & 0.348 & 0.956 & 3.63 \\
VM & 100 & 0.590 & 0.966 & 1.80 \\
RF & & 0.079 & 0.944 & 4.36 \\
\hline VL & & 0.021 & 0.988 & 3.60 \\
VM & 110 & 0.011 & 0.985 & 1.38 \\
RF & & 0.602 & 0.795 & 2.95 \\
\hline VL & & 0.600 & 0.982 & 6.11 \\
VM & 120 & 0.250 & 0.922 & 7.15 \\
RF & & 0.343 & 0.448 & 7.28 \\
\hline VL & & 0.382 & 0.846 & 11.73 \\
VM & 130 & 0.940 & 0.955 & 3.61 \\
RF & & 0.315 & 0.939 & 4.90 \\
\hline
\end{tabular}

ICC резултати из табеле 1 указују на умерену до високу поузданост за све мишиће код свих зглобова осим RF при $120^{\circ}$, који је једини непоуздани резултат између покушаја у овој студији. ANOVA резултати за VL и VM при углу од $110^{\circ}$ су се испоставили као најпоузданији према резултатима ICC (0.988 за VL и 0.985 за VM). Додатно, најмање SEM вредности за ова два мишића су остварене под истим углом (3.60 и 1.38, редом). Све SEM вредности су биле релативно ниске што чини апсолутну поузданост унутар сесије релативно високом (Табела 1). Скоро сви SEM резултати су били у опсегу 1.38-7.28, осим VL на $130^{\circ}$ који је био мало већи (11.73). Другим речима, интервал поузданости од 95\% (у којем ће резултати три узастопна испитивања да се нађу) је релативно узак, што би такође могао бити показатељ добре валидности снимљеног EMG сигнала. Практично, када је у питању анализа између EMG сигнала између узастопних покушаја, коришћење EMG је веома прецизна метода.

\section{Поузданост између сесија}

Табела 2 показује резултате апсолутне и релативне поузданости између сесија. Према Т-тест статистичкој анализи, средње вредности за VL из две одвојене тест-сесије нису значајно различите за све тестиране углове зглоба колена, са највишим $p$ вредностима на углу од $110^{\circ}(p=0.853)$ и најмањим за $100^{\circ}(p=0.163)$. VM и RF такође нису показали значајне разлике између средњих вредности између два тестирања, осим под углом од $80^{\circ}(p=0.006)$. Најмања разлика за VM је била при углу колена од $120^{\circ}$, а за RF када је угао износио $110^{\circ}(p=0.869)$. Када је реч о конзистентности резултата, VL је показао као најконсистентнију поузданост у односу на угао зглоба колена, док је, када је у питању поузданост са најмањом разликом између средњих вредности, VM показао највећу р-вредност под углом колена од $120^{\circ}$. Свеукупно, Т-тест је показао да је VM имао најнижу p-вредност од три праћена мишића, осим када је угао у колену $120^{\circ}$ - тада је VM најпоузданији мишић. 
Кукић Ф., и сар. Поузданост електромиографије..., ФИЗИЧКА КУЛТУРА 2017; 71 (2): 99-110

Табела 2. Статистика поузданости између сесија за све испитане мишиће и углове у зглобу колена

\begin{tabular}{|c|c|c|c|c|}
\hline Muscle & Knee angle & $\begin{array}{c}\text { T-test } \\
p \text { value }\end{array}$ & ICC & SEM \\
\hline VL & & 0.696 & 0.603 & 25.09 \\
\hline VM & 80 & 0.162 & 0.507 & 15.63 \\
\hline RF & & 0.006 & 0.197 & 18.97 \\
\hline VL & & 0.547 & 0.933 & 7.30 \\
\hline VM & 90 & 0.334 & 0.578 & 14.64 \\
\hline RF & & 0.401 & 0.341 & 20.47 \\
\hline VL & & 0.163 & 0.867 & 8.37 \\
\hline VM & 100 & 0.053 & 0.501 & 11.35 \\
\hline RF & & 0.667 & 0.104 & 25.57 \\
\hline VL & & 0.853 & 0.872 & 12.08 \\
\hline VM & 110 & 0.057 & 0.258 & 14.03 \\
\hline RF & & 0.869 & -0.033 & 31.43 \\
\hline VL & & 0.564 & 0.948 & 9.09 \\
\hline VM & 120 & 0.916 & 0.788 & 10.01 \\
\hline RF & & 0.036 & 0.277 & 20.92 \\
\hline VL & & 0.615 & 0.660 & 15.01 \\
\hline VM & 130 & 0.206 & 0.764 & 7.14 \\
\hline RF & & 0.682 & -1.54 & 43.63 \\
\hline
\end{tabular}

У поређењу са Т-тестом, ICC резултати су слични за VL (табела 3). Само је за зглобне углове од $80^{\circ}$ и $130^{\circ}$ ICC била мало испод граничне вредности од 0.75 која је одабрана као најнижа прихватљива вредност за процену поузданости у овом истраживању. Другим речима, VL је показао велику конзистентност у поузданости при целом тестираном опсегу дужине мишића. Са друге стране, за VM и RF разлике између две сесије су биле безначајне за Т-тест већине испитаних углова у зглобу колена, што није био случај и са ICC. Према резултатима за ICC, VM је показао довољну поузданост само за зглобне углове од $120^{\circ}$ и $130^{\circ}$ ( $\mathrm{ICC}=0.788$ и 0.764 , редом), док за RF није пронађена поузданост ни за један испитани зглобни угао. Додатно, резултати SEM су показали најниже вредности управо при зглобним угловима који су били поуздани између два тестирања за VL и VM. Највећа поузданост за SEM је пронађена за VL на зглобним угловима од $110^{\circ}$ (ICC $=0.867$, SEM $=12.08)$, а најнижа за $130^{\circ}$ за VM (ICC $=0.764$, $\mathrm{SEM}=7.14)$ (Табела 2). Другим речима, све поуздане вредности за ICC су биле у опсегу SEM од 7.14-
12.08. У поређењу са поузданошћу унутар сесије, 95\% интервал поузданости за поузданост између сесија је мало, али прихватљиво шири. Међутим, ипак мора бити узет у обзир и исконтролисан код тестирања одвојених недељу дана.

\section{ДИСКУСИЈА}

\section{Поузданост унутар сесије}

Резултати овог истраживања показују да је поузданост унутар сесије висока за све тестиране мишиће током тестираног опсега (ICC $=0.795$ 0.988 и $\mathrm{SEM}=1.38-11.71)$, осим RF за $120^{\circ}$ $(\mathrm{ICC}=0.448)$. Слични резултати за ICC су пронађени у истраживању у којем је испитивана поузданост тестирања између два различита дана при вољној изометријској контракцији (ICC $=0.95$ за VL, 0.97 за VM и 0.96 за RF), доскоку (ICC $=0.90$ заVL и VM, и 0.93 за RF) и при промени правца са вредностима ICC $=0.94$ за VL, 0.88 за VM, и 0.78 за RF (Fauth и сар., 2010). Додатно, Ларсон и сарадници (1999) су испитивали поузданост унутар 
сесије за 3 серије од 10 динамичких контракција и пронашли високу поузданост за VL, VM и RF ca ICC $=0.89-0.96$ за средњу вредност од десет контракција, и ICC $=0.83-0.97$ за контракције са највећим обртним моментом. Штавише, њихови ANOVA резултати показују да у оба случаја не постоји разлика између серија, што се доводи у везу са резултатима нашег истраживања који су показали да нема значајне разлике између средњих вредности код три узастопна понављања у већини испитаних случајева. У нашој студији, само су две $p$ вредности (VL и VM за $110^{\circ}$ ) показале значајну разлику, али је то било пропраћено са високим ICC што може бити последица малог узорка и велике стандардне девијације. Смит и сарадници (2012) су добили да је поузданост унутар сесије умерена до висока за већину коришћених услова ношења и контроле терета. Најнижи ICС износио je 0.34, а највиши 0.94, али је већина ICC резултата била виша од 0.75 уз додатак да резултати за SEM нису били виши од 0.20. Поузданост EMG-a унутар сесије током трчања за VL и RF показала је добру поузданост за RF (0.794), али недовољну за VL (0.394), што је пропраћено са резултатима SEM од 0.126 до 0.075 или нормализованим резултатима за SEM=34.77 и 30.18 (Smoliga et al, 2012). Овакви резултати могу бити последице велике стандардне девијације средњих вредности, што би могао бити узрок великих разлика између испитаника у телесној композицији или разлике у моторним обрасцима између појединаца (Smoliga et al, 2010). Додатно, динамичка активност зависи од промена у дужини и облику мишића, што утиче на EMG сигнал током филтрирања кроз меко ткиво, будући да се растојање између поставке електрода и активне моторне јединице циклично мења (Smoliga et al, 2010).

Иако постоје одређене варијације у апсолутним и релативним вредностима поузданости унутар сессија, наши резултати и резултати других истраживања при динамичким или изометријским контракцијама показују високу поузданост EMG за RMS између узастопних понављања, када једном постављене електроде нису померане. У поређењу изометријске са динамичким контракцијама мишића опружача ногу, изометријски услови контракције недвосмислено показују вишу поузданост за све три испитане мишићне главе квадрицепса. У складу са тим, прва хипотеза наше студије се показала као тачна.

\section{Поузданост између сесија}

Поузданост између сесија је показала умерено до високу поузданост за VL за углове од $90^{\circ}, 100^{\circ}$, $110^{\circ}, 120^{\circ}$ (ICC $=0.872-0.948$ са упареним вредностима за SEM=7.30-9.09, редом), и умерену до високу за $\mathrm{VM}$ при угловима од $120^{\circ}$ и $130^{\circ}$ (ICC $=0.764$ и 0.788 , док је $\mathrm{SEM}=7.14$ и 10.01). Уочено је такође да Т-тест генерално показује најмање разлике између средњих вредности за VL у поређењу са VM и RF, што је додатни доказ да је EMG сигнал за VL најконсистентнији од све три испитане мишићне главе. Проблем са Т-тестом је био тај што показује да нема статистички значајних разлика између средњих вредности у две тестиране сесије за већину испитаних услова. Прецизније, само за RF мишић при једном зглобном углу је уочена значајна разлика између средњих вредности. Ово може бити последица природе Т-теста који мери праволинијску повезаност између два мерења, а не и позицију мере унутар сета података, што није адекватан начин за испитивање поузданости (Larsson et al, 2001). Из тог разлога ово истраживање додатно користи ICC анализу за релативну поузданост, јер она узима у обзир варијансу између испитаника и варијације сваког испитаника. SEM процедура је укључена за процену апсолутне поузданости, која се заснива на стандардним девијацијама резултата свих испитаника и ICC коефицијенту поузданости (Larsson et al, 2003; Mathur et al, 2005; Wier, 2005).

Зглобни угао од $120^{\circ}$ је показао највећу поузданост за VL и VM, док даље повећање мишићне дужине доводи до мање поузданости за VM и недостатак поузданости за VL. Прави мишић бута (RF) није показао поуздану активацију ни у једном од тестираних углова у зглобу колена. Матур и сарадници (2005) показују да је поузданост између тестирања у различитим данима мала до веома велика (ICC $=0.68$ за VL, 0.88 за VM, и 0.91 за RF) током одржавања контракције на $20 \%$ од максимума. Такође су показали умањење нивоа поузданости за RF и повећање за VL, када је интензитет контракције био $80 \%$ од MVC (ICC=0.66 за RF, 0.83 за VM, и 0.84 за VL). Овакви резултати су објашњени обрнутом корелацијом између испољене силе и поузданости за силу - виша сила показује веће варијације између испитаника, што може утицати на поузданост у процени поузданости тестирања у различитим данима (Mathur et al, 2005). У студији Ларсона и сарадника (2003), ре- 
зултати показују недостатак поузданости за три површинске главе квадрицепса када је коришћен нормализовани RMS сигнал (ICC=-0.02 за VM, 0.43 за RF и 0.52 за VL). Иако је била јако ниска, поузданост нормализованог EMG сигнала за VL y овој студији је била виша него за VM и RF (Larsson et al, 2003). Ипак, протокол испитивања у истој студији је подразумевао 100 динамичких покрета где позиција електрода може бити угрожена, и не може се са сигурношћу тврдити да је анализирана иста моторна јединица у свакој узастопној контракцији. Такође, аутори користе другачије методе за нормализацију сигнала што, како они наводе, треба додатно истражити (Larsson et al, 2003). Раинолди и сар. (2001) показују сличне резултате као и у нашем истраживању. Они су користили зглобни угао од $130^{\circ}$ за испитивање изометријске контракције, а за поузданост амплитуде сигнала једино VL је показао поуздану активацију. Могући узрок недостатка поузданости активације за VM може лежати у дужини мишићних влакана на месту где би електроде током испитивања VM требало да буду постављене. Унутрашња глава квадрицепса је мали део мишића близу колена и његова влакна су кратка. Из тог разлога, постављање електрода у различитим данима тестирања могла би да утиче на прикупљени сигнал (Rainoldi et al, 2001). Преклапање актинских и миозинских влакана, као и угао припајања мишића за кост се чине као најоптималније на поменутим мишићним дужинама. Из тог разлога, Голџијев тетивни апарат неће бити нити побуђен нити инхибиран. Штавише, зглобне површинине су у таквим односима да нема великог унутар зглобног притиска, те је предњи укрштени лигамент релативно опуштен, што поново уклања побуђеност, односно инхибираност рефлекса који могу утицати на мишићну активацију (Gandevia, McKenzie, 1998; McGinty et al, 2000). Може се закључити да би угао од $120^{\circ}$ требало да буде најбоља позиција за емитовање EMG сигнала за тестирање квадрицепса при покретима опружања у зглобу колена. Ова мишићна дужина дозвољава максималну активацију мишића у условима када су остали фактори који могу утицати на контракцију сведени на минимум.

Стандардна грешка мерења је углавном коришћења као мера апсолутне поузданости (Larsson et al, 2003; Campy et al, 2009; Mathur et al, 2005; Smith et al, 2012). Резултати Ларсон и сарадника
(2003) су били јако различити када је сигнал EMG нормализован. Када је RMS изражена у V, RF, VM и VL показују велику поузданост (ICC=0.89 за RF, 0.88 за VM и 0.83 за VL) али уз велике вредности $\mathrm{SEM}$ вредности $(\mathrm{SEM}=49,49,63)$. Другим речима, релативна поузданост је била велика, али је апсолутна била мала. Са друге стране, када је RMS нормализован, ICC показује недостатак поузданости и VL има највећи ICC, али SEM вредности су биле знатно ниже (SEM=17 за RF, 19 за VM, и 16 за VL). Кампи и сар. (2009) су испитивали поузданост између сесија за мишиће задње ложе бута током различитих интензитета контракције. За сваки интензитет који је показао поуздане резултате (ICC=0.77-0.92), SEM вредности су биле ниже од 14 (SEM=9.72-13.57). У поређењу за поменутом студијом, наши резултати показују већу релативну поузданост пропраћену са мањим апсолутним мерама поузданости. Даље, резултати Матур и сарадници (2005) сугеришу да 80\% од MVC контракције представља бољи избор од 20\% MVC за испитивање EMG, зато што је релативна поузданост била слична за оба интензитета, али су SEM вредности показале бољу апсолутну поузданост на $80 \%$ MVC. Иако је ICC за RF на 20\% од MVC био већи, његове SEM вредности су биле ниже, као и за VM и VL SEM вредности (9.8-17.2 за 80\% MVC насупрот 14.8-22 за 20\% VMC) (Mathur et al, 2005). Требало би имати на уму да је умерена до висока вредност за ICC пропраћена са вредностима SEM мањим од 15, што је такође случај и у нашем истраживању. Из тог разлога, ово би могао бити доказ добре валидности примењеног приступа и добре прецизности при постављању електрода.

Не може се тврдити да ће два мишића исте регије и сличне функције бити подједнако поуздана. Исто важи и за мишиће екстензоре у зглобу колена, уз чињеницу да ће VL бити више поуздан за вредности RMS него друга два тестирана мишића. Ипак, VM је показао добру поузданост на угловима од $120^{\circ}$ и $130^{\circ}$ у зглобу колена. Разлика између поузданости и непоузданости мишића може бити последица конзистентности у разликама мишићне активације између мишића који прелази један или два зглоба. У односу на VL и VM, RF jе двозглобни мишић што би могло утицати на већу редундантност мишићне активације у неспецифичним условима мишићне контракције, а повећана редундантност утиче на поузданост. 
Насупрот томе, природни начин функционисања RF подразумева његово прилагођавање у складу са односом кук-колено, те се RF показао као врло поуздан у оваквим прилагођавањима (Mathur et al, 2005; Stensdotter et al, 2003; Larsson et al, 2003; Smoliga et al, 2010). Према претходно наведеном, могло би се закључити да поузданост нормализованог RMS-а при MVIC између сесија подлеже бројним факторима, као што су величина узорка, тип контракције, број зглобова који су захваћени, коришћена статистика и мишићна дужина.

\section{ЗАКЉУЧАК}

Ова студија се ठавила ефектима мишићне дужине на поузданост EMG сигнала, и може се извести закључак да поузданост између узастопних понављања није под утицајем промене мишићне дужине ни у једном од тестираних мишића. Са друге стране, када су тест-сесије одвојене 7-8 дана, промена мишићне дужине утиче на поузданост и једно-зглобних и више-зглобних глава квадрицепса током опружања у зглобу колена. Даље, као најпоузданија површинска глава квадрицепса показао се VL, затим VM, док RF није показао поузданост у активацији. Из тог разлога, друга хипотеза ове студије је такође потврђена, зато што је поузданост свих тестираних мишића била под утицајем промене зглобног угла, a VL се показао као најпоузданији од свих тестираних мишића. Додатно, угао од $120^{\circ}$ у зглобу колена се показао као једини поуздани угао и за VL и за VM, што сугерише да је овај угао можда добро решење за тестирање EMG у MVIC, при покрету класичног опружања зглоба колена.с

Ова студија је била кратка експериментална процена могућих методолошких поставки када је у питању коришћење електромиографије током опружања ноге у условима MVIC и различитим зглобним угловима, а могу се донети два практична закључка: 1) RF се може искључити због недостатка поузданости; 2) ако се користе EMG RMS тестирања VL и VM, требало би користити угао од $120^{\circ}$ у зглобу колена.

\section{ОГРАНИЧЕЊА}

Одређена методолошка ограничења могу утицати на примену резултата. Узорак испитаника је био кластеризован, што значи да су испитаници за студију одабрани на основу њихових физичких способности. Опсег година испитаника је био јако мали, а истраживање је подразумевало само мушке испитанике, тако да примена резултата на старију популацију или женску популацију није могућа. Сви испитаници у овом истраживању су били добро физички припремљени и са јако малим процентом масног ткива, тако да је упитна примена резултата на особе са већом количином масног ткива и на гојазне особе. Тестирање MVIC се не може користити са популацијом која има било какве здравствене проблеме који су у вези са вези са зглобом колена.

\section{ЗАХВАЛНОСТ}

Ово истраживање је део мастер тезе: Поузданост EMG сигнала током максималне изометријске контракције m.quadriceps femoris-a на paзличитим мишићним дужинама у отвореном и затвореном кинетичком ланцу, Београд, ФСФВ, Универзитет у Београду.

Ово истраживање је део пројекта Утицај примењене физичке активности на локомотрни, метаболички, психосоцијални и едукативни статус популације Републике Србије, под бројем III47015 и 41007, који је финансиран од стране Министарства науке и образовања Републике Србије - Циклус пројеката 2011-2017.

Волели бисмо да се захвалимо Заводу за спорт и медицину спорта за уступање њихове лабораторије за испитивања. Такође, посебну захвалност дугујемо ПРОФЕКС - Академији здравог живота, за дозволу за коришћење Делсис EMG система. 


\section{ЛИТЕРАТУРА:}

1. Ball, N., \& Scurr, J. (2010). An assessment of the reliability and standardisation of tests used to elicit reference muscular actions for electromyographical normalisation. Journal of Electromyography and Kinesiology, 20(1), 81-88.

2. Burden, A. (2010). How should we normalize electromyograms obtained from healthy participants? What we have learned from over 25years of research. Journal of Electromyography and Kinesiology, 20(6), 1023-1035.

3. Burnett, A., Green, J., Netto, K., \& Rodrigues, J. (2007). Examination of EMG normalisation methods for the study of the posterior and posterolateral neck muscles in healthy controls. Journal of Electromyography and Kinesiology, 17(5), 635-641.

4. Campy, R. M., Coelho, A. J., \& Pincivero, D. M. (2009). EMG-torque relationship and reliability of the medial and lateral hamstring muscles. Medicine and Science in Sports and Exercise, 41(11), 2064-2071.

5. Dankaerts, W., O'Sullivan, P. B., Burnett, A. F., Straker, L. M., \& Danneels, L. A. (2004). Reliability of EMG measurements for trunk muscles during maximal and sub-maximal voluntary isometric contractions in healthy controls and CLBP patients. Journal of Electromyography and Kinesiology, 14(3), 333-342.

6. De Luca, C. J. (1997). The use of surface electromyography in biomechanics. Journal of Applied Biomechanics, 13(2), 135-163.

7. De Luca, C. J. (2002). Surface electromyography: Detection and recording. DelSys Incorporated, 10.

8. Enoka, R. M., \& Duchateau, J. (2015). Inappropriate interpretation of surface EMG signals and muscle fiber characteristics impedes understanding of the control of neuromuscular function. Journal of Applied Physiology, 119(12), 1516-8.

9. Farina, D., Merletti, R., \& Enoka, R. M. (2014). The extraction of neural strategies from the surface EMG: an update. Journal of Applied Physiology, 117(11), 1215-1230.

10. Fauth, M. L., Petushek, E. J., Feldmann, C. R., Hsu, B. E., Garceau, L. R., Lutsch, B. N., \& Ebben, W. P. (2010). Reliability of surface electromyography during maximal voluntary isometric contractions, jump landings, and cutting. The Journal of Strength
\& Conditioning Research, 24(4), 1131-1137.

11. Gandevia, S. C., \& McKenzie, D. K. (1988). Activation of human muscles at short muscle lengths during maximal static efforts. The Journal of Physiology, 407(1), 599-613.

12. Hopkins, W. (2000). Measures of Reliability in Sports Medicine and Science. Sports Medicine, 30(1), 1-15).

13. Larsson, B., Karlsson, S., Eriksson, M., \& Gerdle, B. (2003). Test-retest reliability of EMG and peak torque during repetitive maximum concentric knee extensions. Journal of Electromyography and Kinesiology, 13(3), 281-287.

14. Larsson, B., Månsson, B., Karlberg, C., Syvertsson, P., Elert, J., \& Gerdle, B. (1999). Reproducibility of surface EMG variables and peak torque during three sets of ten dynamic contractions. Journal of Electromyography and Kinesiology, 9(5), 351-357.

15. Mathur, S., Eng, J. J., \& MacIntyre, D. L. (2005). Reliability of surface EMG during sustained contractions of the quadriceps. Journal of Electromyography and Kinesiology, 15(1), 102-110.

16. McGinty, G., Irrgang, J. J., \& Pezzullo, D. (2000). Biomechanical considerations for rehabilitation of the knee. Clinical biomechanics, 15(3), 160-166.

17. Merletti, R., \& Di Torino, P. (1999). Standards for reporting EMG data. Journal of Electromyography and Kinesiology, 9(1), 3-4.

18. Mirka, G. A. (1991). The quantification of EMG normalization error. Ergonomics, 34(3), 343-352.

19. Rainoldi, A., Bullock-Saxton, J. E., Cavarretta, F., \& Hogan, N. (2001). Repeatability of maximal voluntary force and of surface EMG variables during voluntary isometric contraction of quadriceps muscles in healthy subjects. Journal of Electromyography and Kinesiology, 11(6), 425-438.

20. Smith, A. J., Flaxman, T. E., Speirs, A. D., \& Benoit, D. L. (2012). Reliability of knee joint muscle activity during weight bearing force control. Journal of Electromyography and Kinesiology, 22(6), 914-922.

21. Smoliga, J. M., Myers, J. B., Redfern, M. S., \& Lephart, S. M. (2010). Reliability and precision of EMG in leg, torso, and arm muscles during running. Journal of Electromyography and Kinesiolo$g y, 20(1)$, e1-e9. 
22. Stensdotter, A. K., Hodges, P., Mellor, R., Sundelin, G., \& Häger-Ross, C. (2003). Quadriceps activation in closed and in open kinetic chain exercise. Medicine and Science in Sports and Exercise, 35(12), 2043-2047.

23. Wang, L., \& Buchanan, T. S. (2002). Prediction of joint moments using a neural network model of muscle activations from EMG signals. IEEE Transactions on Neural Systems and Rehabilitation Engineering, 10(1), 30-37.
24. Weir, J. P. (2005). Quantifying test-retest reliability using the intraclass correlation coefficient and the SEM. Journal of strength and conditioning research, 19(1), 231-240.

25. Worrell, T. W., Crisp, E., \& Larosa, C. (1998). Electromyographic reliability and analysis of selected lower extremity muscles during lateral step-up conditions. Journal of Athletic Training, 33(2), $156-162$.

\title{
ZUVERLÄSSIGKEIT DER ELEKTROMYOGRAFIE WÄHREND UND ZWISCHEN SETS BEI MAXIMALEN ISOMETRISCHEN KONTRAKTIONEN DES QUADRIZEPS: EINFLUSS DES GELENKWINKELS
}

\begin{abstract}
Zusammenfassung:
Verschiedene Faktoren können Einfluss auf die Zuverlässigkeit von elektromyographischen Signalen (electromyography - EMG) ausüben, von welchen die Art der Kontraktion praktisch die wichtigste ist. Ziel dieser Studie ist es, die Zuverlässigkeit der EMG während einer maximalen Kontraktion (maximal voluntary contraction - MVC) von Extensormuskeln im Kniegelenk bei verschiedenen Gelenkwinkeln im Rahmen eines oder zwischen zwei Sets festzulegen. Neun gesunde, körperlich gut vorbereitete Studenten der Fakultät für Sport und Körperkultur haben auf freiwilliger Basis an diesem Test teilgenommen. Die Grundcharakteristiken der Prüflinge waren: 23+/- 1 Jahr, Körpermasse $80.8+/-7.8 \mathrm{~kg}$ und Körpergröße $182+/-7 \mathrm{~cm}$. Analysiert wurde das EMG-Signal mit 3 unterschiedlichen Köpfen des Musculus quadriceps femoris: äußerer Kopf (VL), innerer Kopf (VM) und gerader Kopf (RF). Die Prüflinge hatten die Aufgabe, 3 möglichst schnelle und möglichst intensive MVC in 6 unterschiedlichen Ausgangswinkeln im Kniegelenk in 2 Sets durchzuführen, die 7 - 8 Tage voneinader lagen. Das statistische intra - class - coefficient - of - correlation - Verfahren (ICC) wurde verwendet, um die relative Zuverlässigkeit auf Ebene des Sets selbst und zwischen den Sets festzustellen, während das standard - error - of - measurement - Verfahren (SEM) angewendet wurde, um die absolute Zuverlässigkeit jedes getesteten Muskels auszurechnen. Alle Muskeln wiesen eine hohe Zuverlässigkeit im Rahmen des gleichen Sets vor (ICC=0.488-0.988 und SEM=1.38-11.35). VL wies eine gute Zuverlässigkeit zwischen den Sets für die Mehrheit der Ausgangsbedingungen (ICC $=0.603-0.948$ ) vor, VM für zwei Gelenkwinkel (ICC120 ${ }^{\circ}=0.764$ und $\mathrm{ICC} 130^{\circ}=0.788$ ), RF zeigte für keinen der Ausgangswinkel im Kniegelenk Zuverlässigkeit. Diese Studie weist darauf hin, dass RF wegen einem Mangel an Zuverlässigkeit zwischen zwei Sets nicht für EMG-Tests während MVC bei einer Beinextension geeignet ist und und dass der Winkel von $120^{\circ}$ bei EMG RMS Tests für VM und VL angewendet werden sollte.
\end{abstract}

Schlüsselwörter: TEST / ZUVERLÄSSIGKEIT / SET ZWISCHEN 7-8 TAGEN / / SET IM LAUFE VON EINEM TAG

Примљен: 01. 03. 2017. Прихваћен: 06. 11.2017. 